\title{
Influence of environmental factors on the development of bottom ice protist communities during the winter-spring transition
}

\author{
Magdalena Różańska1 ${ }^{1}$, Michel Gosselin ${ }^{1, *}$, Michel Poulin $^{2}$, Józef Maria Wiktor ${ }^{3}$, \\ Christine Michel ${ }^{4}$ \\ ${ }^{1}$ Institut des sciences de la mer (ISMER), Université du Québec à Rimouski, 310 Allée des Ursulines, Rimouski, \\ Québec G5L 3A1, Canada \\ ${ }^{2}$ Research Division, Canadian Museum of Nature, PO Box 3443, Station D, Ottawa, Ontario K1P 6P4, Canada \\ ${ }^{3}$ Polish Academy of Sciences, Powstańców Warszawy 55, 81-712 Sopot, Poland \\ ${ }^{4}$ Freshwater Institute, Fisheries and Oceans Canada, 501 University Crescent, Winnipeg, Manitoba R3T 2N6, Canada
}

\begin{abstract}
Seasonal changes in the abundance and taxonomic composition of bottom ice protists (i.e. diatoms, flagellates, and dinoflagellates) were assessed in the first-year landfast ice of Franklin Bay (Canadian Beaufort Sea) from 24 February to 20 June 2004. On each sampling day, bottom seaice protists were collected at sites of high $(>10 \mathrm{~cm})$ and low $(<10 \mathrm{~cm})$ snow cover. The net observed growth rates of diatoms and nanoflagellates were significantly higher during the pre-bloom (24 February to $25 \mathrm{March}$ ) than the bloom (ca. 3 April to 23 May) period under low snow cover but were not different under high snow cover. In contrast, dinoflagellates showed relatively constant net observed growth rate before and during the bloom period under both snow covers. These results indicate that the 3 protist groups responded differently to changes in the light regime during the growth period. The decline of the protist community after the bloom period was related to a combination of factors including nitrogen deficiency and melting processes. Prior to the bloom, flagellated cells, likely heterotrophic, dominated numerically under high snow cover, whereas autotrophic protists, especially solitary diatoms, prevailed under low snow cover. During the bloom period, colonial diatoms such as Nitzschia frigida, N. promare, Navicula sp. 6, N. pelagica, and Fragilariopsis cylindrus dominated the bottom ice community irrespective of snow depth, although abundances were higher under low snow cover. The arborescent colonial $N$. frigida, a key species of landfast ice across circumarctic regions, was the most abundant bottom ice algal diatom throughout the entire season. During the post-bloom period, colonial and solitary diatoms declined more rapidly than nanoflagellates, suggesting that nanoflagellates, presumably heterotrophic, were better adapted to melting sea-ice conditions. Our results demonstrated that the availability of nitrate in the surface water limits the accumulation of algal biomass in the bottom horizon of Arctic landfast ice during the vernal growth season.
\end{abstract}

KEY WORDS: Diatoms $\cdot$ Flagellates $\cdot$ Sea ice $\cdot$ Light $\cdot$ Nutrients $\cdot$ Ice protists $\cdot$ Taxonomic composition $\cdot$ Arctic

\section{INTRODUCTION}

Sea ice plays a significant role in the biology and ecology of polar marine ecosystems, supporting a productive community of ice algae (e.g. Horner 1985, Gosselin et al. 1997) and a high diversity of heterotrophic organisms ranging from bacteria (Riedel et al. 2007a,
2008) to metazoans (reviewed by Schnack-Schiel 2003). The sea-ice cover in the Arctic Ocean affects the amount of heat and gas exchange between the atmosphere and the ocean surface (Delille et al. 2007). Ice thickness and snow cover strongly influence the transmission of photosynthetically active radiation (PAR) through the sea ice, therefore affecting the growth, 
production, and biomass of the bottom ice algal communities (Arrigo 2003, Mundy et al. 2005). It has been estimated that ice algae contribute up to ca. $57 \%$ of the total primary production in the central Arctic Ocean (Gosselin et al. 1997) and between 3 and $25 \%$ in Arctic shelf regions (Legendre et al. 1992). However, considering the reduction in sea-ice thickness and extent over the Arctic Ocean reported during the last $10 \mathrm{yr}$ (Comiso et al. 2008), the contribution of ice algae to total primary production may have changed.

Ice algal communities play an important role in polar ecosystems and have a major influence on various trophic levels of Arctic marine food webs (e.g. Runge \& Ingram 1988, Vézina et al. 1997, Fortier et al. 2002). They serve as a main food source for sympagic (iceassociated) and pelagic herbivorous protists (SimeNgando et al. 1997, Michel et al. 2002) and metazoans (Runge \& Ingram 1988, Nozais et al. 2001), contributing significantly to carbon cycling in Arctic regions (Michel et al. 2006).

The incorporation of protists into sea ice starts during fall at the time of ice formation (Gradinger \& Ikävalko 1998, Riedel et al. 2007b, Różańska et al. 2008). The development of these cells in the bottom ice is very slow in winter, but their numbers increase exponentially in early spring with increasing solar irradiance and air temperature and decreasing brine salinity to reach a maximum prior to the melt period, and then decline rapidly in late spring or early summer with ice melting (Hsiao 1980, Horner 1985, Lavoie et al. 2005).

Historically, taxonomic studies have emphasized bottom ice diatoms, neglecting the identification and enumeration of flagellated cells (e.g. Hsiao 1980, Horner \& Schrader 1982). This may be partly explained by the loss of delicate flagellated cells due to osmotic stress during ice-sample thawing (Garrison \& Buck 1986). To prevent cell lysis, Garrison \& Buck (1986) recommended melting ice core samples in filtered seawater. Since the introduction of this procedure, it has been shown that the total protist carbon biomass in the bottom horizon of Arctic sea ice is dominated by phototrophs (Riedel et al. 2008), whereas the total dinoflagellate carbon biomass is dominated by heterotrophs (Gosselin et al. 1997, Michel et al. 2002). In newly formed sea ice, phototrophic flagellates were generally more abundant than heterotrophic ones (Gradinger \& Ikävalko 1998, Riedel et al. 2007b).

Temporal variations in the abundance of bottom ice diatoms and other protists have been studied in many Arctic regions (Chukchi Sea: Clasby et al. 1976; Alaskan Beaufort Sea: Horner \& Schrader 1982; Barrow Strait: Smith et al. 1988, Welch \& Bergmann 1989; Frobisher Bay: Hsiao 1980; Hudson Bay: Poulin et al. 1983, Gosselin et al. 1985, 1990; Canada Basin: Melnikov et al. 2002); however, few studies have addressed the influence of environmental factors on the taxonomic composition of the bottom ice protist community during the pre-bloom, bloom, and post-bloom periods (but see Horner \& Schrader 1982, Poulin et al. 1983).

The overwintering of the CCGS 'Amundsen' during the Canadian Arctic Shelf Exchange Study (CASES) expedition in the Canadian Beaufort Sea provided a unique opportunity to observe the seasonal variations of bottom landfast ice protist communities in relation to changes in environmental conditions. The aim of this study was to examine seasonal changes in abundance and taxonomic composition of bottom ice diatoms, flagellates and dinoflagellates under 2 contrasting snow covers from mid-winter to late spring. This investigation provides key insights for comparison to previous data collected 3 decades ago in the Canadian (Hsiao 1980) and Alaskan (Horner \& Schrader 1982) Beaufort Sea.

\section{MATERIALS AND METHODS}

Sampling and laboratory analyses. Sampling was conducted on 27 occasions from 24 February to 20 June 2004 at a field station located on first-year landfast ice in Franklin Bay $\left(70^{\circ} 04^{\prime} \mathrm{N}, 126^{\circ} 26^{\prime} \mathrm{W}\right.$; water depth ca. $250 \mathrm{~m})$, southeastern Beaufort Sea, Northwest Territories, Canada (Fig. 1). The station was located $1.5 \mathrm{~km}$ northeast of the overwintering site of the research icebreaker CCGS 'Amundsen' as part of CASES. In Franklin Bay, landfast ice begins to grow by midNovember (Barber \& Hanesiak 2004), reaching a thickness of ca. $2 \mathrm{~m}$ by early May (Riedel et al. 2006). Melting of the sea ice usually starts toward the end of April or in early May and ice breakup occurs in early June (Barber \& Hanesiak 2004).

Routine ice sampling was performed at high $(>10 \mathrm{~cm})$ and low $(<10 \mathrm{~cm})$ snow cover sites. On the last sampling day (20 June), only the low snow cover site remained and was sampled. On each sampling day, 3 to 6 ice cores were collected with a Mark II ice corer (9 cm internal diameter, Kovacs Enterprises) at each snow site. The ice cores were collected within an area of approximately $25 \mathrm{~m}^{2}$ to account for horizontal patchiness in the sea-ice algal biomass (Gosselin et al. 1986, Rysgaard et al. 2001). The bottom $4 \mathrm{~cm}$ section of each ice core was cut off with a stainless steel saw and stored in isothermal plastic containers for subsequent analyses. Bottom ice cores were combined for each snow site. At each snow site, an additional ice core was collected and kept separately in a sterile plastic bag for salinity determination. On each sampling day, surface water samples were collected with a hand-pump system for salinity and nutrient determination. Snow depth and ice thickness were measured on each sampling day, whereas incident and sub-ice irradiances 


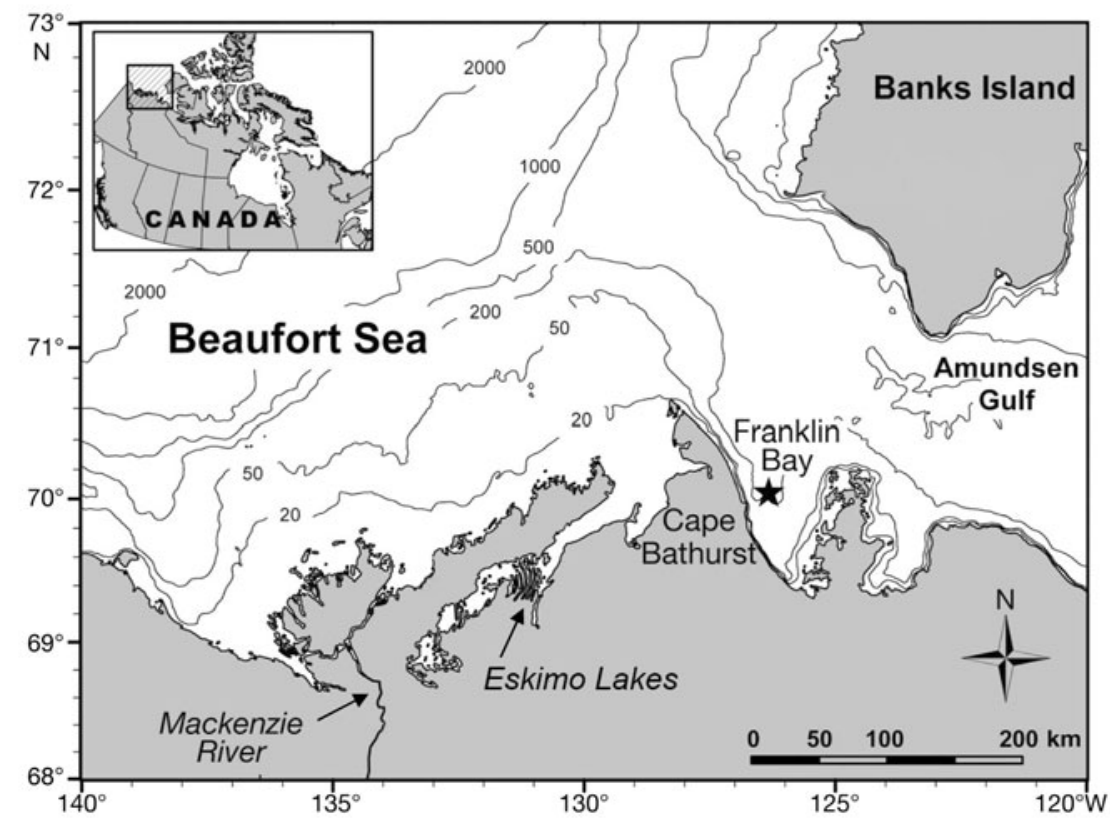

Fig. 1. Canadian Beaufort Sea, showing the location of the overwintering sampling site in Franklin Bay (indicated by star). For comparison, the sampling station area of Hsiao (1980) in Eskimo Lakes is shown. Isobaths: water depth in $\mathrm{m}$ in February and early March when cell abundances were low. For these samples, 100 to $150 \mathrm{ml}$ of subsample were sedimented and between 50 and 300 cells were counted throughout the entire settling chamber. The following references were used for ice protist identification: Poulin \& Cardinal (1982a,b, 1983), Medlin \& Hasle (1990), Medlin \& Priddle (1990), Poulin (1990, 1993), Thomsen (1992), Hasle \& Syvertsen (1997) and von Quillfeldt (1997). Chl $a$ and POC concentrations and protist abundances were corrected for the dilution effect of added seawater as described by Cota \& Sullivan (1990). In the present study, we use the term 'nanoflagellates', since flagellates $>20 \mu \mathrm{m}$ accounted, on average, for only $5.8 \%$ of the total flagellate abundance. These large flagellates $(20-80 \mu \mathrm{m})$ belonged to the class Euglenophyceae or were unidentified flagellates $>20 \mu \mathrm{m}$.

The surface water sample was filtered $(<13 \mathrm{~Pa})$ through pre-combusted Whatman GF/F filters, and the filtrate were measured using Li-Cor $2 \pi$ PAR sensors (LI190SA quantum and LI-192SA underwater quantum sensors, respectively) on 18 March and on 13 occasions between 8 April and 28 May. Incident downwelling irradiance was also recorded with a Li-Cor PAR $2 \pi$ sensor every 10 min from 24 February to 23 May, and air temperature was measured every 2 to $6 \mathrm{~h}$ throughout the study period.

In the ship's laboratory, the ice core samples were slowly melted in a known volume of filtered $(0.2 \mu \mathrm{m}$ polycarbonate membrane) surface seawater to avoid osmotic stress to ice protists (Bates \& Cota 1986, Garrison \& Buck 1986). Duplicate subsamples were filtered through Whatman GF/F glass fiber filters for chlorophyll a ( chl a) determination. Chl a concentrations were determined onboard using a Turner Designs 10-AU fluorometer after $24 \mathrm{~h}$ extraction in $10 \mathrm{ml}$ of $90 \%$ acetone at $5^{\circ} \mathrm{C}$ in the dark (Parsons et al. 1984a). Duplicate subsamples for particulate organic carbon (POC) and nitrogen (PON) were filtered on pre-combusted $\left(450^{\circ} \mathrm{C}\right.$ for $5 \mathrm{~h}$ ) Whatman GF/F filters, stored at $-80^{\circ} \mathrm{C}$, and later analyzed with a Perkin-Elmer Model $2400 \mathrm{CHN}$ analyzer (Knap et al. 1996). For the identification and enumeration of protists, melted ice subsamples were preserved with acidic Lugol's solution (Parsons et al. 1984a). Cells $\geq 4 \mu \mathrm{m}$ were identified to the lowest possible taxonomic rank and enumerated under an inverted microscope (WILD Heerbrugg) equipped with phase contrast optics (Lund et al. 1958). A minimum of 400 cells was counted in each settling chamber, except for 4 samples was immediately frozen at $-80^{\circ} \mathrm{C}$ in acid-cleaned polypropylene cryogenic vials for the analysis of nitrate+ nitrite $\left(\mathrm{NO}_{3}+\mathrm{NO}_{2}\right)$, nitrite $\left(\mathrm{NO}_{2}\right)$, phosphate $\left(\mathrm{PO}_{4}\right)$ and silicic acid $\left(\mathrm{Si}[\mathrm{OH}]_{4}\right)$ using an Alpkem FSIII nutrient autoanalyzer (adapted from Grasshoff et al. 1999). The salinity of both undiluted ice cores and surface water was determined with a Guildline 8400B Autosal Lab salinometer (Knap et al. 1996).

Statistical analyses. Kendall's coefficient of rank correlation $(\tau)$ and Wilcoxon signed-ranks tests were computed to infer relationships between 2 variables and to compare paired variates from the low and high snow cover sites, respectively (Sokal \& Rohlf 1995). The net specific accumulation rates of diatoms, nanoflagellates, and dinoflagellates in the bottom ice were estimated using model I linear regressions between the natural logarithm (ln) of cell abundances and different periods (i.e. prior, during, or following the ice algal bloom). The regression slope, hereafter referred to as the net observed growth rate $\left(r_{\mathrm{n}}\right)$, represents a conservative estimate of the specific growth rate $(\mu)$ of protists because losses (e.g. natural mortality, grazing, sinking) from the sion slopes were compared using analysis of covariance (ANCOVA; Sokal \& Rohlf 1995). A Monod-type equation (Monod 1942) relating the $\log _{10}$ of maximum bottom ice chl a biomasses $(B)$ to the mean $\mathrm{NO}_{3}$ concentrations in the surface water or the upper water column $(S)$ was fitted to the data compiled from the present study and other Arctic sampling stations by nonlinear regresbottom ice are not accounted for (Landry 1993). Regres- 
sion using the Gauss-Newton algorithm. The equation used was:

$$
B=B_{\max } \times S /\left(K_{\mathrm{m}}+S\right)
$$

where $K_{\mathrm{m}}$ is the $\mathrm{NO}_{3}$ concentration at half the maximal biomass $\left(B_{\max }\right)$. Statistical tests and regressions were performed using StatSoft Statistica 6.

\section{RESULTS}

Physico-chemical variables showed a large temporal variability in Franklin Bay during the study period (Figs. 2 \& 3 , Table 1). The incident irradiance increased gradually from $0.3 \mathrm{~mol}$ photons $\mathrm{m}^{-2} \mathrm{~d}^{-1}$ on 24 February to $57.3 \mathrm{~mol}$ photons $\mathrm{m}^{-2} \mathrm{~d}^{-1}$ on 23 May (Fig. 2a) in parallel with the sunlight period, which steadily increased from $8.3 \mathrm{~h}$ at the beginning of the sampling to $24 \mathrm{~h}$ on 8 May and remained at this value for the rest of the study. Air temperature increased from $-35^{\circ} \mathrm{C}$ to $1.3^{\circ} \mathrm{C}$ during the study (Fig. 2b). Seasonally averaged snow depth at the high and low snow sites was 15.6 and $3.8 \mathrm{~cm}$, respectively (Table 1). Sea-ice thickness under both snow covers increased from $1.32 \mathrm{~m}$ on 24 February to a maximum of $2.01 \mathrm{~m}$ on 26 May, and decreased thereafter to reach $1.55 \mathrm{~m}$ on 20 June (Fig. 2c). There was no significant difference in ice thickness between the 2 snow sites (Table 1). Surface water salinity remained relatively constant at 29.6, on average, until 29 May, after which it decreased to reach 5.4 on 20 June (Fig. 2d). Bottom ice salinity ranged from 5.9 to 12.8 throughout the sampling period and was not significantly different between the 2 snow sites (Table 1). The salinity of the diluted ice cores ranged from 20 to 24.5, except on 20 June when it was ca. 5.

Sub-ice irradiance was 2.6 and $5.8 \mu \mathrm{mol}$ photons $\mathrm{m}^{-2} \mathrm{~s}^{-1}$ under high and low snow cover, respectively, corresponding to 0.5 and $1.1 \%$ of the incident irradiance on 18 March under $1.67 \mathrm{~m}$ of ice. When the sea ice was thicker from 8 April to 28 May, sub-ice irradiance ranged from 0.2 to $4.0 \mu \mathrm{mol}$ photons $\mathrm{m}^{-2} \mathrm{~s}^{-1}$ under high snow cover and from 2.9 to $26.0 \mu \mathrm{mol}$ photons
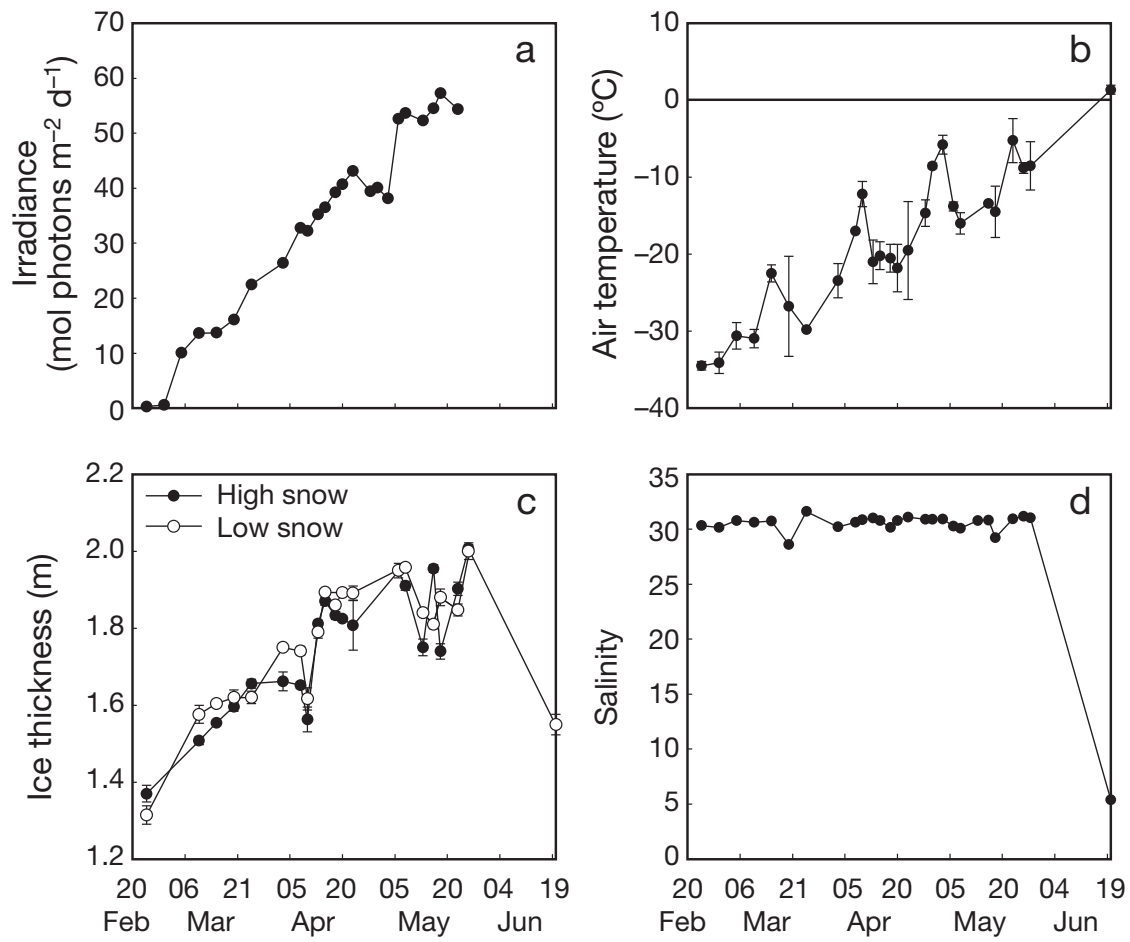

Fig. 2. Temporal variations of (a) incident irradiance, (b) air temperature, (c) ice thickness under high $(>10 \mathrm{~cm})$ and low $(<10 \mathrm{~cm})$ snow cover, and (d) surface water salinity in Franklin Bay from February to June 2004. In (b) and (c), mean values \pm SD are shown
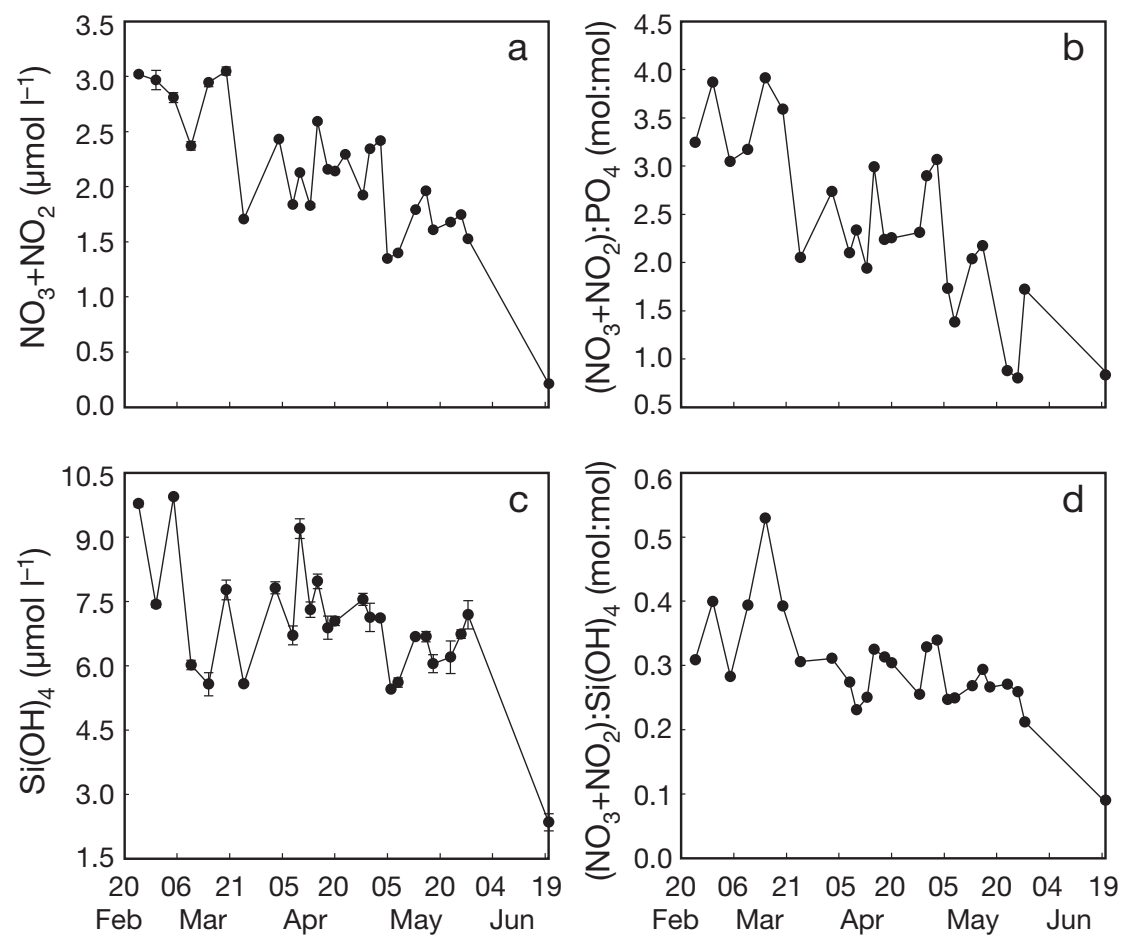

Fig. 3. Temporal variations of (a) nitrate+nitrite $\left(\mathrm{NO}_{3}+\mathrm{NO}_{2}\right)$ concentration, (b) ratio of $\mathrm{NO}_{3}+\mathrm{NO}_{2}$ to phosphate $\left(\mathrm{PO}_{4}\right)$, (c) silicic acid $\left(\mathrm{Si}[\mathrm{OH}]_{4}\right)$ concentration, and (d) ratio of $\mathrm{NO}_{3}+\mathrm{NO}_{2}$ to $\mathrm{Si}(\mathrm{OH})_{4}$ in the surface water in Franklin Bay from February to June 2004. In (a) and (c), mean values \pm SD are shown 


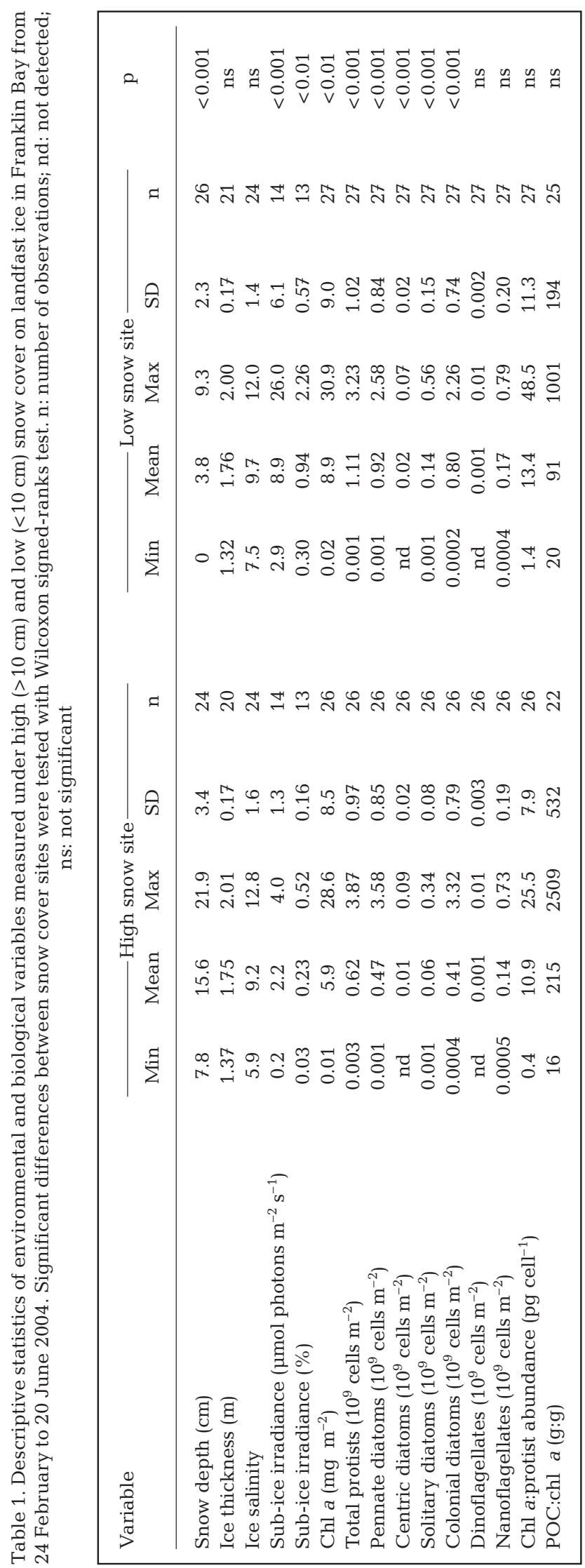

$\mathrm{m}^{-2} \mathrm{~s}^{-1}$ under low snow cover (Table 1$)$. The transmitted irradiance through the snow, ice, and algal layer varied between 0.03 and $0.5 \%$ and between 0.3 and $2.3 \%$ of incident PAR under high and low snow cover, respectively (Table 1). Sub-ice and percent transmitted irradiance were significantly lower under high snow than low snow cover and did not show any seasonal trend (Table 1).

Surface water $\mathrm{NO}_{3}+\mathrm{NO}_{2}$ and $\mathrm{Si}(\mathrm{OH})_{4}$ concentrations decreased from 3.0 to 0.2 and 9.8 to $2.4 \mu \mathrm{mol} \mathrm{l}^{-1}$, respectively, throughout the sampling period and were both negatively correlated with the time of year $(\tau=-0.51$, $\mathrm{p}<0.001$ and $\tau=-0.32, \mathrm{p}<0.05$, respectively; Fig. 3a,c). Surface water $\mathrm{NO}_{2}$ and $\mathrm{PO}_{4}$ concentrations ranged from $\leq 0.05$ (i.e. the detection limit) to $0.14 \mu \mathrm{mol} \mathrm{l}^{-1}$ and 0.23 to $2.18 \mathrm{mmol}^{-1}$, respectively, and did not show any temporal trend. The $\left(\mathrm{NO}_{3}+\mathrm{NO}_{2}\right): \mathrm{PO}_{4}$ and $\left(\mathrm{NO}_{3}+\mathrm{NO}_{2}\right)$ : $\mathrm{Si}(\mathrm{OH})_{4}$ molar ratios decreased throughout the sampling season $(\tau=-0.42, \mathrm{p}<0.01$ and $\tau=-0.47, \mathrm{p}<0.001$, respectively; Fig. 3b,d) and were always lower than the critical Redfield values of 16 for $\left[\mathrm{NO}_{3}+\mathrm{NO}_{2}\right]: \mathrm{PO}_{4}$ and 1.1 for $\left[\mathrm{NO}_{3}+\mathrm{NO}_{2}\right]: \mathrm{Si}(\mathrm{OH})_{4}$ (Redfield et al. 1963). This indicates that dissolved nitrogen was potentially the limiting nutrient for bottom ice algal growth.

Chl a concentrations were $<1.16 \mathrm{mg} \mathrm{m}^{-2}$ in sea ice under both snow covers prior to the bloom period (ca. 3 April to 23 May) and were barely detectable $\left(<0.02 \mathrm{mg} \mathrm{m}^{-2}\right)$ at the beginning of the sampling in late February. Bottom ice chl a concentration started to increase in early March under low snow cover and $1 \mathrm{wk}$ later under high snow cover (Fig. 4a). A steady increase in chl a concentrations was observed afterward, with maximum values of $28.6 \mathrm{mg} \mathrm{m}^{-2}$ on 23 May and $30.9 \mathrm{mg} \mathrm{m}^{-2}$ on 16 May under high and low snow cover, respectively. The bloom period was followed by a sharp decline in chl a concentrations to a minimum value of $0.72 \mathrm{mg} \mathrm{m}^{-2}$ on 20 June (Fig. 4a). Bottom ice protist abundances paralleled the seasonal trends in chl a over the entire sampling period (Fig. 4a,b). Total protist abundances were $<0.01 \times 10^{9}$ cells $\mathrm{m}^{-2}$ in late February and reached maximum values of $3.87 \times$ $10^{9}$ cells $\mathrm{m}^{-2}$ on 6 May and $3.23 \times 10^{9}$ cells $\mathrm{m}^{-2}$ on 18 May under high and low snow cover, respectively (Fig. 4b). The decline in protist abundance was observed after 23 May under both snow covers (Fig. 4b). $\mathrm{Chl}$ a concentrations and protist abundances were significantly lower and more variable under high snow compared to low snow cover (Table 1, Fig. 4a,b).

The ratio of chl a to protist abundance ranged from 0.4 to $25.5 \mathrm{pg} \mathrm{cell}^{-1}$ and 1.4 to $48.5 \mathrm{pg} \mathrm{cell}^{-1}$ under high and low snow cover, respectively (Fig. 4c). During the pre-bloom period, the chl a:protist abundance ratios (pg chl a:cell) were significantly lower in sea ice under high snow than low snow cover (Wilcoxon signedranks test, $\mathrm{p}<0.05$ ). This situation was reversed during 
the bloom and post-bloom periods, when the ratio was higher in sea ice under high snow than low snow cover (Wilcoxon signed-ranks test, $\mathrm{p}<0.01$; Fig. 4c). The POC:chl a ratio (g:g) varied between 16 and $2509 \mathrm{~g}: \mathrm{g}$ and 20 and $1001 \mathrm{~g}: \mathrm{g}$ in sea ice under high and low snow cover, respectively (Fig. 4d). The ratio was significantly higher under high snow (mean of 215) than low snow (mean of 91) cover during the prebloom period (Wilcoxon signed-ranks test, $\mathrm{p}<0.05$ ), while there was no statistical difference in the POC:chl a ratio for the rest of the season under both snow covers (mean of 45; Wilcoxon signed-ranks test, $\mathrm{p}=0.76$ )

The abundances of diatoms, nanoflagellates, and dinoflagellates increased progressively until 23 May under both snow covers (Fig. 5a,c). Diatoms and nanoflagellates were always more abundant than dinoflagellates. However, pennate and centric diatoms were significantly less abundant in sea ice under high snow than low snow cover, while nanoflagellate and dinoflagellate abundances were not significantly different between the 2 snow covers for the entire sampling period (Table 1). Prior to the bloom, diatom and nanoflagellate abundances were not significantly different in sea ice under high snow cover $(p=0.24)$, whereas diatoms were almost 4 times more abundant than nanoflagellates under low snow cover $(\mathrm{p}<0.05$; Fig. 5a,c). In contrast, during the bloom period, diatoms were significantly more abundant than nanoflagellates in sea ice under high snow cover (diatom numbers twice higher; $\mathrm{p}<0.01$ ) and under low snow cover (diatom numbers ca. 5 times higher; $\mathrm{p}<0.001)$.

Colonial and solitary diatom abundances increased steadily until 23 May (Fig. 5b,d). Prior to the bloom, the colony-forming diatoms were significantly less abundant than solitary diatoms in sea ice under high snow cover (Wilcoxon signed-ranks test, p < 0.05), while the abundances of colonial and solitary diatoms were not significantly different under low snow cover (Wilcoxon signed-ranks test, $\mathrm{p}=0.31$ ). Dur-
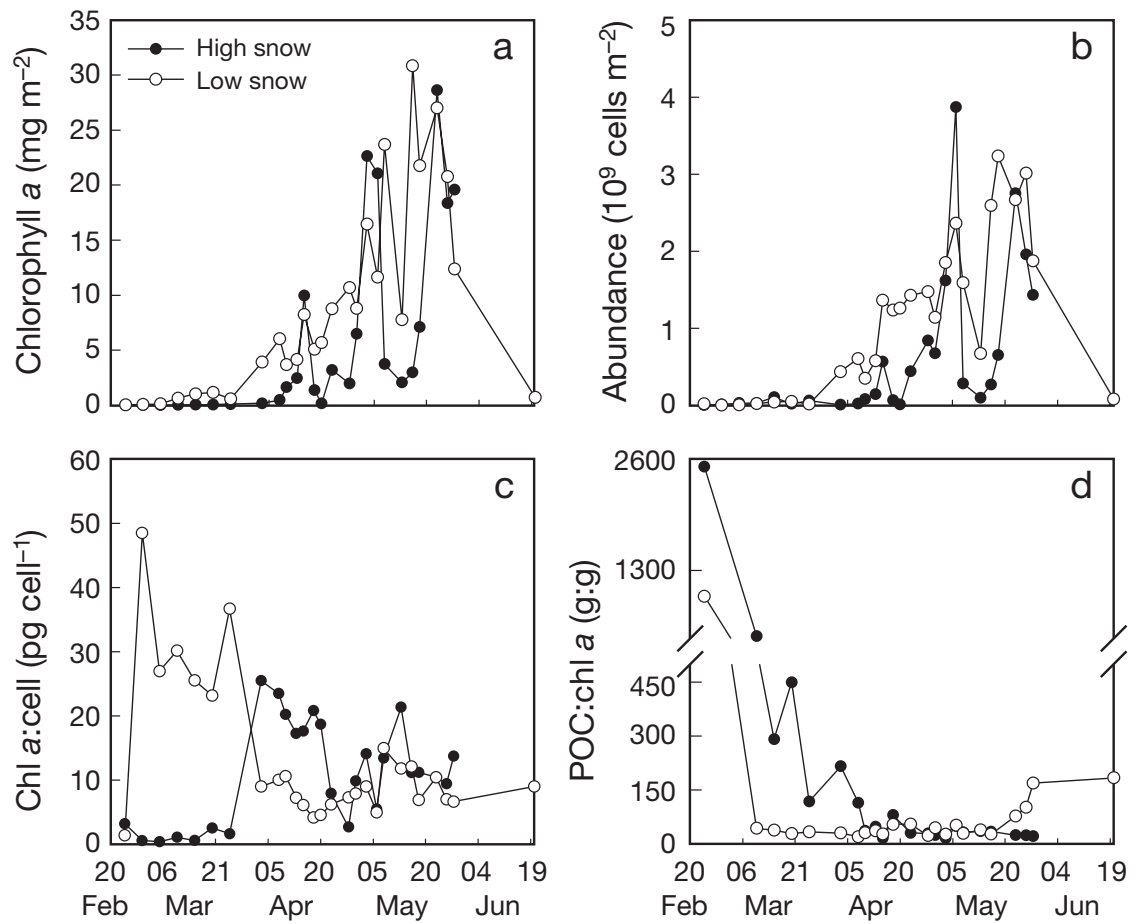

Fig. 4. Temporal variations of (a) chlorophyll a (chl a) concentration, (b) total cell abundance (i.e. diatoms + flagellates + dinoflagellates), (c) ratio of chl a to total protist abundance, and (d) ratio of particulate organic carbon (POC) to chl $a$ in the bottom ice under high $(>10 \mathrm{~cm})$ and low $(<10 \mathrm{~cm})$ snow cover in Franklin Bay from February to June 2004
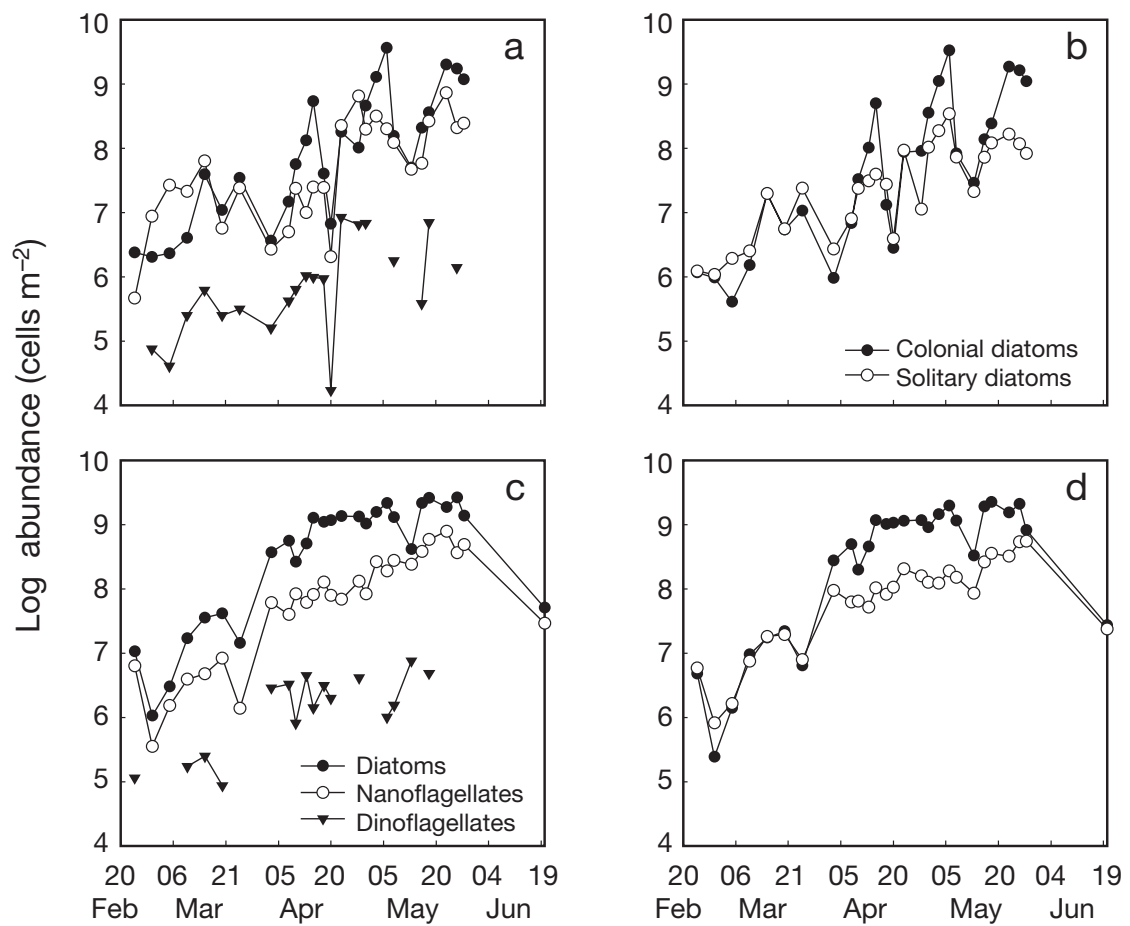

Fig. 5. Temporal variations of the abundances of $(\mathrm{a}, \mathrm{c})$ diatoms, nanoflagellates and dinoflagellates, and $(b, d)$ solitary and colonial diatoms in the bottom ice under $(a, b)$ high $(>10 \mathrm{~cm})$ and $(\mathrm{c}, \mathrm{d})$ low $(<10 \mathrm{~cm})$ snow cover in Franklin Bay from February to June 2004. In (a) and (c), the discontinuous line indicates that dinoflagellates were not detected on these dates 
ing the bloom period, the colony-forming diatoms were significantly more abundant than solitary diatoms in sea ice under high (diatom numbers ca. 5 times higher, $\mathrm{p}<0.01$ ) and low (diatom numbers ca. 6 times higher, $\mathrm{p}<0.001$ ) snow cover, respectively (Fig. 5b,d). The percentage of empty diatom cells increased throughout the study under both snow covers (Table 2).

The net observed growth rates of diatoms and nanoflagellates were significantly higher during the prebloom than the bloom period under the low snow cover sites (ANCOVA, p < 0.001) but not statistically different under high snow cover sites (ANCOVA, p > 0.05, Table 2). In addition, the net observed growth rates of diatoms and nanoflagellates were lower in sea ice under high snow compared to low snow cover prior to the bloom, whereas they were higher under high than low snow cover during the bloom (Table 2). However, these differences were not significant (ANCOVA, $p>0.05)$. Due to the large variability in cell counts, the net observed growth rates of dinoflagellates during the pre-bloom and bloom periods were not significantly different from 0 under both snow covers (Model I regressions, $p>0.05$ ). However, the estimated net observed growth rates of dinoflagellates from 24 February to 23 May were $0.043 \mathrm{~d}^{-1}(\mathrm{SE}=0.010)$ under high snow cover and $0.047 \mathrm{~d}^{-1}(\mathrm{SE}=0.009)$ under low snow cover (Model I regressions, $\mathrm{p}<0.001$ ); these 2 rates were not significantly different (ANCOVA, $p=0.78$ ).

During this study, a total of 149 and 140 bottom ice protist taxa representing 119 and 112 species in 12 algal classes were recorded for high and low snow cover, respectively (Appendix 1). The bottom ice protist community was composed of 106 pennate diatom taxa, 8 centric diatoms, 29 flagellates, and 10 dinoflagellates, with diatoms representing $75 \%$ of the total protist taxa. The highest numbers of diatom taxa were recorded in the genera Navicula Bory and Nitzschia Hassall. The arborescent colonial diatom Nitzschia frigida was the most abundant diatom during our sam- pling period (Appendix 1). Dinoflagellate cysts were observed in only 1 sample collected under high snow cover, with an average abundance of $5 \times 10^{3}$ cells $\mathrm{m}^{-2}$.

The taxonomic composition of the bottom ice protist community varied seasonally and differed under high and low snow cover. During the pre-bloom period, unidentified flagellates $(<10 \mu \mathrm{m})$ were the most abundant along with Nitzschia frigida, N. arctica, and Cylindrotheca closterium under high snow cover, whereas $N$. frigida was the most abundant species along with $C$. closterium, Fragilariopsis cylindrus, and unidentified flagellates $(<10 \mu \mathrm{m})$ under low snow cover. During the bloom period, high snow cover sites were characterized by a higher number of protist taxa, with a predominance of colony-forming diatoms of the genera Nitzschia and Navicula followed by unidentified flagellates $(<10 \mu \mathrm{m})$ along with scattered solitary diatom cells. Under low snow cover sites, the community was characterized by a strong predominance of colonial diatoms belonging to Nitzschia frigida, Nitzschia promare, Navicula sp. 6, and Navicula pelagica. During the post-bloom period, the same colonial diatom species were still making up the bottom ice community, with the predominance of Nitzschia frigida along with Navicula sp. 6, Navicula pelagica, and Nitzschia promare, except in a higher proportion under high snow than low snow cover. In addition, the abundance of unidentified flagellates $(<10 \mu \mathrm{m})$ was higher under low snow cover.

Under both snow covers, chl a concentrations and diatom and nanoflagellate abundances were positively correlated with time of year, incident irradiance, air temperature, and ice thickness, and negatively correlated with surface water $\mathrm{NO}_{3}+\mathrm{NO}_{2}$ (Table 3). In contrast to the other biological variables, dinoflagellate abundance was not correlated with ice thickness under either snow cover or with air temperature under low snow cover (Table 3). Chl a concentrations and diatom and nanoflagellate abundances were not significantly

Table 2. Average percent numbers of empty diatom cells and estimated $( \pm \mathrm{SE})$ net observed growth rate $\left(r_{\mathrm{n}}\right)$ of diatoms and nanoflagellates under high $(>10 \mathrm{~cm})$ and low $(<10 \mathrm{~cm})$ snow cover during the bottom ice algal pre-bloom $(24$ February to $25 \mathrm{March})$, bloom (ca. 3 April to 23 May), and post-bloom (high snow: 23 to 28 May; low snow: 23 May to 20 June) periods. Negative $r_{n}$ values indicate a decline in cell abundances. All rates were significantly different from 0 ( $\mathrm{p} \leq 0.05)$, except values in italics; na: data not available

\begin{tabular}{|c|c|c|c|c|c|}
\hline & \multirow{2}{*}{ Empty diatoms (\%) } & \multirow[b]{2}{*}{ Total } & \multirow{2}{*}{$\begin{array}{c}\text { Diatom } r_{\mathrm{n}}\left(\mathrm{d}^{-1}\right) \\
\text { Colonial }\end{array}$} & \multirow[b]{2}{*}{ Solitary } & \multirow{2}{*}{ Nanoflagellate $r_{\mathrm{n}}\left(\mathrm{d}^{-1}\right)$} \\
\hline & & & & & \\
\hline \multicolumn{6}{|c|}{ High snow cover } \\
\hline Pre-bloom & 4.9 & $0.10 \pm 0.028$ & $0.10 \pm 0.038$ & $0.10 \pm 0.025$ & $0.09 \pm 0.054$ \\
\hline Bloom & 14.4 & $0.08 \pm 0.025$ & $0.09 \pm 0.030$ & $0.06 \pm 0.025$ & $0.09 \pm 0.022$ \\
\hline Post-bloom & 29.9 & na & na & na & na \\
\hline \multicolumn{6}{|c|}{ Low snow cover } \\
\hline Pre-bloom & 3.5 & $0.20 \pm 0.032$ & $0.23 \pm 0.044$ & $0.18 \pm 0.027$ & $0.15 \pm 0.028$ \\
\hline Bloom & 18.9 & $0.03 \pm 0.009$ & $0.03 \pm 0.009$ & $0.03 \pm 0.006$ & $0.05 \pm 0.006$ \\
\hline Post-bloom & 60.1 & $-0.15 \pm 0.012$ & $-0.16 \pm 0.022$ & $-0.13 \pm 0.010$ & $-0.11 \pm 0.018$ \\
\hline
\end{tabular}


Table 3. Kendall's coefficients of rank correlation $(\tau)$ between environmental and biological variables under high $(>10 \mathrm{~cm})$ and low snow $(<10 \mathrm{~cm})$ cover. Pairwise deletion of missing data; ${ }^{*} \mathrm{p} \leq 0.05 ;{ }^{* *} \mathrm{p} \leq 0.01 ;{ }^{* * *} \mathrm{p} \leq 0.001$; ns: not significant

\begin{tabular}{|lcccc|}
\hline & Chl $a$ & Diatoms & $\begin{array}{c}\text { Nano- } \\
\text { flagellates }\end{array}$ & $\begin{array}{c}\text { Dino- } \\
\text { flagellates }\end{array}$ \\
\hline High snow & & & & \\
$\quad$ Time of year & $0.74^{* * *}$ & $0.66^{* * *}$ & $0.51^{* *}$ & $0.53^{*}$ \\
Incident irradiance & $0.67^{* * *}$ & $0.59^{* * *}$ & $0.44^{* *}$ & $0.52^{*}$ \\
Air temperature & $0.65^{* * *}$ & $0.59^{* * *}$ & $0.49^{* *}$ & $0.38^{*}$ \\
Ice thickness & $0.63^{* * *}$ & $0.57^{* *}$ & $0.38^{*}$ & $0.23^{\text {ns }}$ \\
Surface $\mathrm{NO}_{3}+\mathrm{NO}_{2}$ & $-0.46^{*}$ & $-0.43^{*}$ & $-0.33^{*}$ & $-0.34^{*}$ \\
Surface $\mathrm{Si}(\mathrm{OH})_{4}$ & $-0.16^{\mathrm{ns}}$ & $-0.22^{\text {ns }}$ & $-0.18^{\mathrm{ns}}$ & $-0.03^{\mathrm{ns}}$ \\
Low snow & & & & \\
Time of year & $0.71^{* * *}$ & $0.66^{* * *}$ & $0.73^{* * *}$ & $0.52^{*}$ \\
Incident irradiance & $0.80^{* * *}$ & $0.77^{* * *}$ & $0.74^{* * *}$ & $0.48^{*}$ \\
Air temperature & $0.57^{* * *}$ & $0.57^{* * *}$ & $0.56^{* * *}$ & $0.24^{\mathrm{ns}}$ \\
Ice thickness & $0.62^{* * *}$ & $0.67^{* * *}$ & $0.55^{* *}$ & $0.30^{\text {ns }}$ \\
Surface $\mathrm{NO}_{3}+\mathrm{NO}_{2}$ & $-0.40^{* *}$ & $-0.35^{* *}$ & $-0.40^{*}$ & $-0.52^{*}$ \\
Surface $\mathrm{Si}(\mathrm{OH})_{4}$ & $-0.21^{\mathrm{ns}}$ & $-0.15^{\text {ns }}$ & $-0.17^{\mathrm{ns}}$ & $-0.15^{\mathrm{ns}}$ \\
\hline
\end{tabular}

correlated with the other environmental variables (e.g. surface water $\mathrm{Si}[\mathrm{OH}]_{4}$ and $\mathrm{PO}_{4}$ ). Surface water $\mathrm{NO}_{3}+$ $\mathrm{NO}_{2}, \mathrm{Si}(\mathrm{OH})_{4}$ and $\mathrm{PO}_{4}$ concentrations were not significantly correlated with surface salinity.

\section{DISCUSSION}

The dynamics of algae and heterotrophic protists in sea ice has only rarely been investigated in the Arctic during the winter-spring transition period (e.g. Riedel et al. 2006, 2007a, 2008). This study reports one of the most complete seasonal time series on the taxonomic composition and abundance of bottom ice diatoms, nanoflagellates, and dinoflagellates in the Arctic under 2 contrasting irradiance conditions. In this section, we discuss: (1) the role of meteorological and hydrodynamic factors with respect to the temporal variability of the protist community, (2) the influence of snow cover on the net observed growth rates, cell abundance, and taxonomic composition of diatoms and other protists throughout the study period, (3) the importance of improving our knowledge on the ecology of heterotrophic protists and key ice species, and (4) the significance of nutrient supply for the largescale horizontal distribution of chl a biomass in the bottom ice.

\section{Seasonal and short-term variability}

During the present study, the chl a biomass and protist abundance in the bottom landfast ice horizon increased gradually from the end of February to the end of May, in parallel with seasonal increases in incident irradiance, air temperature, and ice thickness (Figs. 2a-c \& 4a,b, Table 1). The protist community then declined rapidly during the melt period, following the increase in air temperature and decreases in ice thickness and surface water salinity.

As the season progressed, there was evidence that surface water $\mathrm{NO}_{3}$ concentration decreased gradually as a result of its consumption by algae (Figs. 3a \& $4 \mathrm{a}, \mathrm{b})$. This is supported by the negative correlations between surface $\mathrm{NO}_{3}$ concentration and bottom ice chl a biomass and protist abundances under both snow covers (Table 3). This is also supported by estimates of the depletion time of dissolved inorganic nitrogen (DIN; i.e. the ratio of DIN concentration to net daily accumulation rate of $\mathrm{PON}$ ) by bottom ice algae during the bloom period, using data from the same sampling sites published by Riedel et al. (2008). Based on the net daily accumulation rates of POC in the bottom ice, the POC:PON molar ratio of 7.0 and the median DIN concentrations in the bottom ice for the bloom period, we calculated a depletion time of DIN of 0.6 to $1.0 \mathrm{~d}$. Hence, without replenishment from the water column, DIN at the ice-water interface would have been rapidly depleted by ice algal consumption.

From the seasonal pattern observed, 3 periods in the bottom ice protist development were distinguished. Based on trends under low snow cover, these periods were: (1) a pre-bloom period (24 February to $25 \mathrm{March}$ ) characterized by low chl a biomass and cell abundance but high net observed growth rates, (2) a bloom period (3 April to 23 May) defined by a rapid increase in chl a biomass and cell concentrations and lower net observed growth rates, and (3) a declining phase (postbloom, after 23 May) that coincided with the start of the ice melt (Fig. 4a,b). A similar pattern was also observed under high snow cover; however, the bloom at these sites was delayed by $1 \mathrm{wk}$, and the net observed growth rates did not decrease during the bloom period. In addition, the chl a biomass and total protist abundance were generally lower under the high snow cover, as discussed in the next section. The seasonal pattern observed is typical for the bottom landfast ice community reported throughout the Arctic (Gosselin et al. 1990, Welch et al. 1991, Michel et al. 1996).

During the bloom period, the ice protist community also showed short-term variability superimposed on the seasonal trend. The decrease in bottom ice chl a biomass and protist abundance from 6 to 13 May (Fig. 4a,b) under both snow covers coincided with an increase in biogenic silica sinking fluxes in the upper 
$25 \mathrm{~m}$ of the water column (Juul-Pedersen et al. 2008). Since this event occurred during the spring tide, we hypothesize that part of the bottom ice community was washed away by stronger tidal currents. In addition, relatively elevated bottom ice chl a biomass and protist abundance compared to the general trend were measured under high snow cover on 13 April, 3 to 6 May, and 23 May (Fig. 4a,b). These values were similar to those determined under low snow cover at this time of the year. This suggests that sites sampled on these days were likely covered by little (or less) snow prior to sampling. Hence, the patchy distribution of the bottom ice protist communities under the high snow cover can be attributed to shifting snowdrifts and new snow. These results support the hypothesis that meteorological and hydrodynamic forcings affect the temporal and horizontal variability of the bottom ice protist community in the southeastern Beaufort Sea, as has been shown in other Arctic environments by Gosselin et al. (1985, 1986), Welch et al. (1991), and Mundy et al. (2007).

\section{Snow cover effect on net observed growth rate, cell abundance, and taxonomic composition of ice protists}

Throughout the sampling period, the net observed growth rate, abundance, and taxonomic composition of the bottom ice photosynthetic protists were influenced by snow cover depth, which strongly influences light transmission through the ice sheet (Perovich 1990, Belzile et al. 2000). Indeed, diatom abundance was significantly lower under high snow cover, while nanoflagellates and dinoflagellates showed no differences between the 2 snow depths (Table 1). In addition, the bottom ice algal bloom, which was mostly composed of pennate diatoms, was delayed by $1 \mathrm{wk}$ under high snow cover (Figs. 4a,b \& 5), as mentioned previously. These results indicate that diatoms were more affected by light conditions than nanoflagellates and dinoflagellates. These latter 2 groups were composed of photosynthetic and heterotrophic organisms, as discussed in the next section.

By the end of February, the bottom ice irradiance was sufficient to allow diatom growth under low snow cover (Fig. 5c). Unfortunately, sub-ice irradiance was measured only on 1 occasion prior to the bloom period. On $18 \mathrm{March}$, the sub-ice irradiance was 2.6 and $5.8 \mu \mathrm{mol}$ photons $\mathrm{m}^{-2} \mathrm{~s}^{-1}$ under high and low snow cover, respectively. These values are within the range of irradiance sufficient to trigger the growth of autotrophic protists in the bottom ice horizon (i.e. 2 to $9 \mu \mathrm{mol}$ photons $\mathrm{m}^{-2} \mathrm{~s}^{-1}$; Horner \& Schrader 1982, Gosselin et al. 1985).

Under low snow cover sites, the net observed growth rates of diatoms and nanoflagellates were significantly higher before $\left(0.15\right.$ to $\left.0.23 \mathrm{~d}^{-1}\right)$ than during (0.03 to
$0.09 \mathrm{~d}^{-1}$ ) the bloom period (Table 2). This seasonal decrease in net observed growth rates was also observed for algae determined by epifluorescence microscopy from the same sampling site (Riedel et al. 2008). This general pattern of decreasing net observed growth rate, as the biomass of protists accumulates in the environment, is similar to that observed during phytoplankton development in a stratified water column (Parsons et al. 1984b). The smaller net observed growth rates later in the season may result from losses of bottom ice protist cells by sinking, grazing, viral lysis, and/or ablation.

In contrast to sites under low snow cover, the net observed growth rates of diatoms and nanoflagellates under high snow cover remained relatively constant during the pre-bloom and bloom periods. This difference in net observed growth rates between the 2 snow cover sites may be explained by earlier nutrient limitation under low snow sites due to the higher algal biomass (Gosselin et al. 1990, Smith et al. 1997) or, alternatively, by less intense grazing pressure on the protist community by copepods and other metazoans (Nozais et al. 2001, Seuthe et al. 2007) under the high snow cover site due to the lower food availability. It is interesting to note that the net observed growth rate of dinoflagellates was relatively constant during the prebloom and bloom periods under both snow covers (i.e. 0.04 to $0.05 \mathrm{~d}^{-1}$ ). This result suggests that this group, which was not affected by the light regime, was mainly composed of heterotrophic organisms, as discussed in the next section.

The decline of the bottom ice community under both snow covers after 23 May was related to a combination of factors including nutrient deficiency, as suggested by the sudden increase in POC:chl a ratios from ca. 41 to $184 \mathrm{~g}: \mathrm{g}$ after $23 \mathrm{May}$, and melting processes, as indicated by the thinning of the sea ice and the freshening of the surface water.

The taxonomic composition was also affected by the snow cover depth throughout the study. Colonial and solitary diatom taxa were more abundant under low snow than high snow cover (Table 1). Among the colonial pennate diatoms, Nitzschia frigida, Navicula sp. 6, Nitzschia promare, Navicula septentrionalis, Pseudonitzschia cf. pseudodelicatissima, Nitzschia neofrigida, Entomoneis kjellmanii, Nitzschia arctica, Synedropsis hyperborea, Pauliella taeniata, and Entomoneis kjellmanii var. kariana were at least 2 to 3 times more abundant under low snow than high snow cover, whereas the centric diatom Melosira arctica was 16 times more abundant (Appendix 1). The only solitary centric diatom showing higher abundances under low snow cover was the epiphytic species Attheya septentrionalis, which was mainly attached to $N$. frigida, as previously reported by von Quillfeldt (1997). Even 
though the total abundance of nanoflagellates was not affected by snow depth, the colonial species Dinobryon faculiferum and flagellates $>10 \mu \mathrm{m}$ were 2 to 3 times more abundant under low snow than high snow cover, while the heterotrophic species Telonema subtilis (Shalchian-Tabrizi et al. 2006) was 2 times more abundant under high snow cover (Appendix 1). Hence, snow cover depth is a key factor influencing the composition of the bottom ice protist community from late winter to the end of spring.

\section{Heterotrophic organisms}

There is evidence that the flagellate community was dominated by heterotrophic organisms prior to the bloom period under high snow cover. First, the low chl a:protist abundance ratio $\left(<3.15 \mathrm{pg} \mathrm{cell}^{-1}\right)$ and high POC:chl a ratio (>118 g:g) under high snow compared to low snow cover (Fig. 4c,d) indicate a predominance of heterotrophic biomass in the bottom ice prior to 3 April. Secondly, these observations are supported by direct enumeration of heterotrophic bacteria and protists using epifluorescence microscopy by Riedel et al. (2007a). This is also supported by a carbon budget indicating that heterotrophs represented $72 \%$ of the total carbon biomass (i.e. heterotrophic protists + bacteria + algae) under high snow cover compared to $15 \%$ under low snow cover during the pre-bloom period (Riedel et al. 2008).

The occurrence of phagotrophic taxa such as Telonema subtilis, choanoflagellates, and unidentified Gymnodinium/Gyrodinium indicates that heterotrophic protists were present under both snow covers throughout the study (Appendix 1). Furthermore, microscopic observations of diatom cells ingested by dinoflagellates and Euglenophyceae indicate that phagotrophic activity was occurring during the bloom period, as observed by Riedel et al. (2007a). As reported by these authors, heterotrophic flagellates were probably using dissolved organic carbon, exopolymeric substances, bacteria, and/or small algae to satisfy their energy requirements. Hence, bottom ice flagellates and dinoflagellates are composed of a mixed community of autotrophic, heterotrophic, and mixotrophic protists, which needs to be studied in more detail.

\section{Key species}

Regardless of the snow thickness on sea ice during the study, the taxonomic composition of the bottom ice diatom community was comparable to that reported in other Arctic landfast ice regions (Hsiao 1980, Horner \& Schrader 1982, Poulin et al. 1983, Okolodkov 1992, Rat- kova \& Wassmann 2005). These studies showed that pennate diatoms dominated over centric diatoms, except in White Sea landfast and pack ice (Ratkova \& Wassmann 2005). We recorded a total of 95 pennate and 6 centric diatom taxa in Franklin Bay, which is comparable to the values ranging from 91 to 139 pennate and 7 to 16 centric diatoms reported from Eskimo Lakes, Eclipse Sound, and Frobisher Bay (Hsiao 1980), southeastern Hudson Bay (Poulin et al. 1983), and the Laptev, East Siberian, and Chukchi Seas (Okolodkov 1992). However, these numbers are low compared to the 233 diatom taxa recorded from 2 cores collected on first-year pack ice of the Chukchi Sea by von Quillfeldt et al. (2003).

The arborescent colonial species Nitzschia frigida was the most abundant diatom during this study. However, Fragilariopsis cylindrus (formerly Nitzschia cylindrus [Grunow] Hasle) was reported as the most abundant diatom species in the Alaskan Beaufort Sea during the bottom ice algal bloom (Horner \& Schrader 1982). In Franklin Bay, this species never represented more than $1.4 \%$ of the total diatom abundance. N. frigida has been frequently observed in many other circumarctic regions, such as the Chukchi Sea (Okolodkov 1992, von Quillfeldt et al. 2003), Eskimo Lakes (Hsiao 1980), Resolute Passage (Sime-Ngando et al. 1997), Eclipse Sound and Frobisher Bay (Hsiao 1980), Northeast Water off Greenland (von Quillfeldt 1997), the White and Barents Seas (Ratkova \& Wassmann 2005), and the Laptev and East Siberian Seas (Okolodkov 1992) as well as in the central Arctic Ocean (Booth \& Horner 1997, Gosselin et al. 1997). The consistent occurrence of $N$. frigida in bottom sea ice throughout the Arctic can be explained by the fact that this species is extremely well-adapted to a wide range of light regimes. Indeed, Hegseth (1992) showed in the laboratory that this species can grow well at a constant temperature of $-0.5^{\circ} \mathrm{C}$ under irradiances varying from 10 to $400 \mu \mathrm{mol}$ photons $\mathrm{m}^{-2} \mathrm{~s}^{-1}$, maintaining a maximum growth rate at irradiances from 50 to $400 \mu \mathrm{mol}$ photons $\mathrm{m}^{-2} \mathrm{~s}^{-1}$. The physiological characteristics of $N$. frigida make it the most frequent and most abundant species of the Arctic sea-ice habitat.

During the present study, 3 classes of diatoms and 9 classes of flagellated cells were found in the bottom ice of Franklin Bay (Appendix 1). These numbers are comparable to the 7 and 12 non-diatom algal classes reported in the sea ice of the North Water (northern Baffin Bay) by Simard (2003) and the Barents and White Seas by Ratkova \& Wassmann (2005), respectively, during the spring. In Arctic sea-ice studies, the importance of pico-, nano-, and microflagellates has been largely overlooked, due in part to methodological problems inherent to the melting process of sea-ice samples (Garrison \& Buck 1986). Some chrysophytes and dinoflagellates have been previously recognized 
at the species level, but very often these non-diatom cells have simply been grouped together and listed as unidentified flagellates (e.g. Hsiao 1980, Horner \& Schrader 1982, Poulin et al. 1983, Okolodkov 1992). However, working with non-preserved samples, Ikävalko \& Gradinger (1997) identified 40 and 43 flagellate taxa belonging to 10 classes in newly formed sea ice and multi-year ice floes, respectively. Therefore, when the aim is to identify flagellated cells or other delicate protists, it is highly recommended to adequately prepare melted sea-ice samples in the field following the method of Garrison \& Buck (1986) or collect brine samples (Stoecker et al. 1997) and to identify live cells with light or electron microscopy, to maintain cultures, or to use current molecular tools (Lovejoy et al. 2006). This will improve our knowledge of this understudied protist group.

\section{Influence of nutrient supply on the large-scale horizontal distribution of bottom ice algae}

The maximum bottom ice chl a concentration of $31 \mathrm{mg} \mathrm{m}^{-2}$ recorded during this study is similar to concentrations reported for Barrow, Alaska $\left(27 \mathrm{mg} \mathrm{m}^{-2}\right.$; Lee et al. 2008), the Alaskan Beaufort Sea $\left(27 \mathrm{mg} \mathrm{m}^{-2}\right.$; Horner \& Schrader 1982), Jones Sound (23 $\mathrm{mg} \mathrm{m}^{-2}$; Apollonio 1965), Frobisher Bay (30 $\mathrm{mg} \mathrm{m}^{-2}$; Hsiao 1980), and southeastern Hudson Bay (25-40 $\mathrm{mg} \mathrm{m}^{-2}$; Gosselin et al. 1986, 1990), but 2 to 10 times lower than the values recorded for northwestern Hudson Bay (170 $\mathrm{mg} \mathrm{m}^{-2}$; Welch et al. 1991) and Resolute Passage (77-325 $\mathrm{mg} \mathrm{m}^{-2}$; Smith et al. 1988, Michel et al. 1996). of a strong halocline at the base of the winter mixed layer, which restricts nutrient-rich waters of Pacific origin from entering the euphotic zone. As the maximum biomass attained in the bottom ice can be limited by nutrient supply (Maestrini et al. 1986, Welch et al. 1991), it is plausible that the $\mathrm{NO}_{3}$ availability is responsible for the relatively low ice algal biomass reached during the bloom period in the Canadian Beaufort Sea and possibly in other Arctic regions.

To test this hypothesis, maximum bottom ice chl a concentrations reported from different studies conducted on Arctic first-year landfast ice were plotted against mean surface water $\mathrm{NO}_{3}$ concentrations observed during the vernal growth season (Fig. 6). The data show a Monod-type relationship between the 2 variables, with chl a concentrations up to $320 \mathrm{mg} \mathrm{m}^{-2}$ at $\mathrm{NO}_{3}$ concentrations $\geq 6 \mu \mathrm{mol} \mathrm{l}^{-1}$ (Fig. 6). This equation fits the data very well $\left(\mathrm{r}^{2}=0.91\right)$. These results indicate that the availability of $\mathrm{NO}_{3}$ in the surface water can be limiting for the accumulation of bottom ice algae during the spring bloom in Arctic waters. In nitrate-rich waters (e.g. $>12 \mu \mathrm{mol} \mathrm{l^{-1 }}$ ), however, dense algal populations may experience some degree of light limitation from self-shading toward the bottom of the algal horizon (Cota \& Horne 1989).

In the Alaskan Beaufort Sea (Horner \& Schrader 1982) and at Barrow, Alaska (Lee et al. 2008), the maximum chl a concentration is 1 order of magnitude lower than values from other stations with similar surface water $\mathrm{NO}_{3}$ concentrations (Fig. 6). Disruption of the bottom ice skeletal layer by strong currents and tides (see Lee et al. 2008), reduced light transmission to the bottom ice caused by sediments entrapped in the top
Since the sunlight period and snow conditions are comparable in all of these Arctic regions, the differences in bottom ice algal biomass are probably related to the water column dynamics and nutrient supply. In Franklin Bay, surface water $\mathrm{NO}_{3}$ was low compared to $\mathrm{PO}_{4}$ and $\mathrm{Si}(\mathrm{OH})_{4}$ (Fig. 3) and could have limited the accumulation of algal biomass in the bottom ice horizon. In this study, surface water $\mathrm{NO}_{3}$ concentrations $\left(0.2-3.1 \mathrm{\mu mol} \mathrm{l}^{-1}\right)$ were similar to those reported for southeastern Hudson Bay $\left(0.2-3.3 \mu \mathrm{mol} \mathrm{l^{-1 }}\right.$; Gosselin et al. $1985,1990)$ but several times lower than those from the Alaskan Beaufort Sea (6-9 $\mu \mathrm{mol} \mathrm{^{-1 }}$; Horner \& Schrader 1982) and Barrow Strait $\left(2-10 \mu \mathrm{mol} \mathrm{l^{-1 }}\right.$; Cota et al. 1990). Carmack et al. (2004) proposed that low $\mathrm{NO}_{3}$ availability in the upper water column of the Canadian Beaufort Sea results from the formation

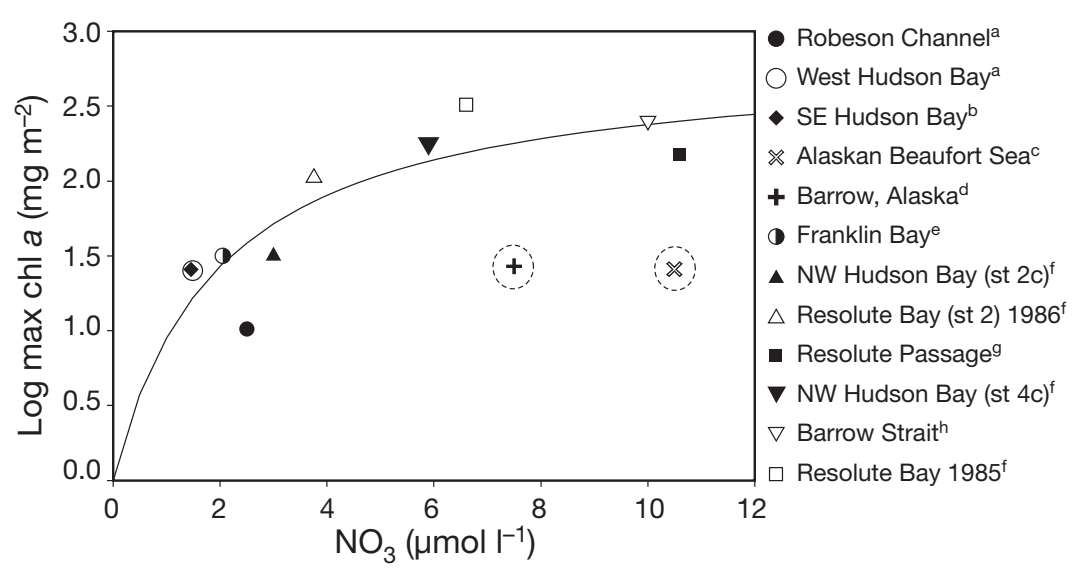

Fig. 6. Relationship between maximum bottom ice chlorophyll a (chl a) concentrations and $\mathrm{NO}_{3}$ concentrations in the surface water from different studies conducted on Arctic first-year landfast ice: ${ }^{a}$ Dunbar \& Acreman (1980), ${ }^{b}$ Gosselin et al. (1990), ${ }^{C}$ Horner \& Schrader (1982), ${ }^{d}$ Lee et al. (2008), ${ }^{e}$ present study, ${ }^{f}$ Welch et al. (1991), ' ${ }^{\mathrm{L}}$ evasseur et al. (1994), and ${ }^{\mathrm{h}} \mathrm{Smith}$ et al. (1990). In Welch et al. (1991), $\mathrm{NO}_{3}$ concentrations were measured in the upper water column. Note log scale on $y$-axis. The curve is calculated using Eq. (1); $B_{\max }=2.85, K_{\mathrm{m}}=1.99 \mu \mathrm{mol} \mathrm{l}^{-1}$, $\mathrm{r}^{2}=0.91$. Dashed encircled data were excluded from the regression 
sea-ice layer, nutrient deficiency by an element other than nitrogen, viral lysis, or intense grazing pressure may have limited the accumulation of algae in the bottom ice at these shallow Alaskan coastal sites (i.e. 4 to $7 \mathrm{~m}$ ) in spring.

Our overall results indicate that the small-scale horizontal variability in ice algal biomass and composition is controlled by snow distribution, whereas the largescale distribution may be governed by nutrient supply from the water column. This supports the early model of bottom ice dynamics proposed by Gosselin et al. (1985) and Welch et al. (1991), in which the production of ice algal biomass is controlled not only from above, by the seasonal changes in irradiance, but also from below, by the vertical mixing that replenishes the icewater interface with nutrients, and as recently shown by Lavoie et al. (2005) in a coupled sea-ice model of ice algal growth and decline.

\section{CONCLUSIONS}

In the Canadian Beaufort Sea, the accumulation of algae and other protists in the bottom horizon of firstyear landfast ice starts as early as the end of February, with higher net observed growth rates of diatoms and nanoflagellates during the pre-bloom than during the bloom period under low snow cover. In contrast, the net observed growth rate of dinoflagellates did not change during the bloom period under both snow covers. These results show the differential response of the bottom ice protist communities to changes in the light regime during the winter-spring transition.

Flagellated cells represented, on average, $28 \%$ of the total protist abundance. Past studies have underestimated the occurrence and abundance of this group in Arctic sea ice. Prior to the bloom, flagellated cells, which were presumably heterotrophic, dominated under high snow cover, whereas autotrophic protists, especially solitary diatoms, prevailed under low snow cover. During the bloom period, colonial diatoms dominated in the bottom ice community irrespective of the snow depth, although higher abundances were observed under low snow cover. Moreover, the arborescent colonial diatom Nitzschia frigida was the most abundant bottom ice algal species throughout the entire season. $N$. frigida can be considered a key species of landfast ice across circumarctic regions. During the post-bloom period, the decline of colonial and solitary diatom abundances was faster than that of nanoflagellates, suggesting that nanoflagellates, presumably heterotrophic (Riedel et al. 2008), can survive under melting sea-ice conditions.

Finally, our study indicates that the maximum bottom ice algal biomass attained during the vernal growth season may depend on nitrate supply from the upper water column. Hence, the amount of nutrients available in the surface water column at the end of the winter is an important factor determining the magnitude of the ice algal spring bloom, as recently shown by the sea-ice algal model of Lavoie et al. $(2005,2009)$.

Acknowledgements. This project was funded by grants from the Natural Sciences and Engineering Research Council (NSERC) of Canada (Research Network grant to M.G., M.P., and C.M.; Individual Discovery grant to M.P.; Individual and Northern Research Supplement Discovery grants to M.G.) and by financial support from the Canadian Museum of Nature to M.P. Partial operating funds for the CCGS 'Amundsen' were provided by the International Joint Ventures Fund of the Canada Foundation for Innovation and the Fonds québécois de la recherche sur la nature et les technologies (FQRNT). M.R. received post-graduate scholarships from ISMER and the Université du Québec à Rimouski. We thank the officers and crew of the CCGS 'Amundsen' for their invaluable support during the expeditions; A. Riedel, B. LeBlanc, T. Juul-Pedersen, P. Galbraith, P. Larouche, T. Buzinski, L. Seuthe, S. Kirillov, and A. Tatarek for assistance in the field or laboratory; M. Simard and M. Gauthier for nutrient analysis; T. Papakyriakou for providing incident irradiance data and Y. Gratton for tidal elevation predictions; and L. Devine and 3 anonymous reviewers for constructive comments on the manuscript. This is a contribution to the research programs of CASES, ISMER, and Québec-Océan.

\section{LITERATURE CITED}

Apollonio S (1965) Chlorophyll in Arctic sea-ice. Arctic 18: $118-122$

Arrigo KR (2003) Primary production in sea ice. In: Thomas DN, Dieckmann GS (eds) Sea ice. An introduction to its physics, chemistry, biology and geology. Blackwell Science, Oxford, p 143-183

Barber DG, Hanesiak JM (2004) Meteorological forcing of sea ice concentrations in the southern Beaufort Sea over the period 1979 to 2000. J Geophys Res 109, C06014, doi: 10.1029/2003JC002027

Bates SS, Cota GF (1986) Fluorescence induction and photosynthetic responses of Arctic algae to sample treatment and salinity. J Phycol 22:421-429

Belzile C, Johannessen S, Gosselin M, Demers S, Miller W (2000) Ultraviolet attenuation by dissolved and particulate constituents of first year ice during late spring in an Arctic polynya. Limnol Oceanogr 45:1265-1273

Booth BC, Horner RA (1997) Microalgae on the Arctic Ocean Section, 1994: species abundance and biomass. Deep-Sea Res II 44:1607-1622

Carmack EC, Macdonald RW, Jasper S (2004) Phytoplankton productivity on the Canadian Shelf of the Beaufort Sea. Mar Ecol Prog Ser 277:37-50

Clasby RC, Alexander V, Horner R (1976) Primary productivity of sea-ice algae. In: Hood DW, Burrell DC (eds) Assessment of the Arctic marine environment: selected topics. Inst Mar Sci Univ Alaska, Fairbanks, AK, p 289-304

Comiso JC, Parkinson CL, Gersten R, Stock L (2008) Accelerated decline in the Arctic sea ice cover. Geophys Res Lett 35, L01703, doi:10.1029/2007GL031972

Cota GF, Horne EPW (1989) Physical control of arctic ice algal production. Mar Ecol Prog Ser 52:111-121 
Cota GF, Sullivan CW (1990) Photoadaptation, growth and production of bottom ice algae in the Antarctic. J Phycol 26:399-411

Cota GF, Anning JL, Harris LR, Harrison WG, Smith REH (1990) Impact of ice algae on inorganic nutrients in seawater and sea ice in Barrow Strait, NWT, Canada, during spring. Can J Fish Aquat Sci 47:1402-1415

Delille B, Jourdain B, Borges AV, Tison JL, Delille D (2007) Biogas $\left(\mathrm{CO}_{2}, \mathrm{O}_{2}\right.$, dimethylsulfide) dynamics in spring Antarctic fast ice. Limnol Oceanogr 52:1367-1379

Dunbar MJ, Acreman JC (1980) Standing crops and species composition of diatoms in sea ice from Robeson Channel to the Gulf of St. Lawrence. Ophelia 19:61-72

> Fortier M, Fortier L, Michel C, Legendre L (2002) Climatic and biological forcing of the vertical flux of biogenic particles under seasonal Arctic sea ice. Mar Ecol Prog Ser 225:1-16

Garrison DL, Buck KR (1986) Organism losses during ice melting: a serious bias in sea ice community studies. Polar Biol 6:237-239

Gosselin M, Legendre L, Demers S, Ingram RG (1985) Responses of sea-ice microalgae to climatic and fortnightly tidal energy inputs (Manitounuk Sound, Hudson Bay). Can J Fish Aquat Sci 42:999-1006

Gosselin M, Legendre L, Therriault JC, Demers S, Rochet M (1986) Physical control of the horizontal patchiness of seaice microalgae. Mar Ecol Prog Ser 29:289-298

Gosselin M, Legendre L, Therriault JC, Demers S (1990) Light and nutrient limitation of sea-ice microalgae (Hudson Bay, Canadian Arctic). J Phycol 26:220-232

Gosselin M, Levasseur M, Wheeler PA, Horner RA, Booth BC (1997) New measurements of phytoplankton and ice algal production in the Arctic Ocean. Deep-Sea Res II 44: 1623-1644

Gradinger R, Ikävalko J (1998) Organism incorporation into newly forming Arctic sea ice in the Greenland Sea. J Plankton Res 20:871-886

Grasshoff K, Kremling K, Ehrhardt M (1999) Methods of seawater analysis, 3rd edn. Wiley-VCH, New York, NY

Hasle GR, Syvertsen EE (1997) Marine diatoms. In: Tomas CR (ed) Identifying marine phytoplankton. Academic Press, San Diego, CA, p 5-385

Hegseth EN (1992) Sub-ice algal assemblages of the Barents Sea: species composition, chemical composition, and growth rates. Polar Biol 12:485-496

Horner R (1985) Ecology of sea ice microalgae. In: Horner RA (ed) Sea ice biota. CRC Press, Boca Raton, FL, p 83-103

Horner R, Schrader GC (1982) Relative contributions of ice algae, phytoplankton, and benthic microalgae to primary production in nearshore regions of the Beaufort Sea. Arctic 35:485-503

Hsiao SIC (1980) Quantitative composition, distribution, community structure and standing stock of sea ice microalgae in the Canadian Arctic. Arctic 33:768-793

Ikävalko J, Gradinger R (1997) Flagellates and heliozoans in the Greenland Sea ice studied alive using light microscopy. Polar Biol 17:473-481

> Juul-Pedersen T, Michel C, Gosselin M, Seuthe L (2008) Seasonal changes in the sinking export of particulate material under first-year sea ice on the Mackenzie Shelf (western Canadian Arctic). Mar Ecol Prog Ser 353:13-25

Knap A, Michaels A, Close A, Ducklow H, Dickson A (1996) Protocols for the Joint Global Ocean Flux Study (JGOFS) core measurements. JGOFS Report No. 19, Reprint of the Intergovernmental Oceanographic Commission. Manuals and Guides No. 29, UNESCO, Bergen

Landry MR (1993) Estimating rates of growth and grazing mortality of phytoplankton by the dilution method. In:
Kemp PF, Sherr BF, Sherr EB, Cole JJ (eds) Handbook of methods in aquatic microbial ecology. Lewis Publishers, Boca Raton, FL, p 715-723

> Lavoie D, Denman K, Michel C (2005) Modeling ice algal growth and decline in a seasonally ice-covered region of the Arctic (Resolute Passage, Canadian Archipelago). J Geophys Res 110, C11009, doi:10.1029/2005JC002922

Lavoie D, Macdonald RW, Denman KL (2009) Primary productivity and export fluxes on the Canadian Shelf of the Beaufort Sea: a modeling study. J Mar Syst 75:17-32

> Lee SH, Whitledge TE, Kang SH (2008) Spring time production of bottom ice algae in the landfast ice zone at Barrow, Alaska. J Exp Mar Biol Ecol 367:204-212

Legendre L, Martineau MJ, Therriault JC, Demers S (1992) Chlorophyll a biomass and growth of sea-ice microalgae along a salinity gradient (southeastern Hudson Bay, Canadian Arctic). Polar Biol 12:445-453

> Levasseur M, Gosselin M, Michaud S (1994) A new source of dimethylsulfide (DMS) for the arctic atmosphere: ice diatoms. Mar Biol 121:381-387

Lovejoy C, Massana R, Pedrós-Alió C (2006) Diversity and distribution of marine microbial eukaryotes in the Arctic Ocean and adjacent seas. Appl Environ Microbiol 72: 3085-3095

Lund JWG, Kipling C, Le Cren ED (1958) The inverted microscope method of estimating algal numbers and the statistical basis of estimations by counting. Hydrobiologia 11: $143-170$

Maestrini SY, Rochet M, Legendre L, Demers S (1986) Nutrient limitation of the bottom-ice microalgal biomass (southern Hudson Bay). Limnol Oceanogr 31:969-982

> Medlin LK, Hasle GR (1990) Some Nitzschia and related diatom species from fast ice samples in the Arctic and Antarctic. Polar Biol 10:451-479

Medlin LK, Priddle J (1990) Polar marine diatoms. British Antarctic Survey, Cambridge

> Melnikov IA, Kolosova EG, Welch HE, Zhitina LS (2002) Sea ice biological communities and nutrient dynamics in the Canada Basin of the Arctic Ocean. Deep-Sea Res I 49: 1623-1649

> Michel C, Legendre L, Ingram RG, Gosselin M, Levasseur M (1996) Carbon budget of ice algae in spring: evidence of a significant transfer to zooplankton grazers. J Geophys Res 101(C8):18345-18360

> Michel C, Nielsen TG, Nozais C, Gosselin M (2002) Significance of sedimentation and grazing by ice micro- and meiofauna for carbon cycling in annual sea ice (northern Baffin Bay). Aquat Microb Ecol 30:57-68

Michel C, Ingram RG, Harris LR (2006) Variability in oceanographic and ecological processes in the Canadian Arctic Archipelago. Prog Oceanogr 71:379-401

Monod J (1942) Recherches sur la croissance des cultures bactériennes, 2nd edn. Hermann, Paris

Mundy CJ, Barber DG, Michel C (2005) Variability of snow and ice thermal, physical and optical properties pertinent to sea ice algae biomass during spring. J Mar Syst 58:107-120

> Mundy CJ, Ehn JK, Barber DG, Michel C (2007) Influence of snow cover and algae on the spectral dependence of transmitted irradiance through Arctic landfast first-year sea ice. J Geophys Res 112, C03007, doi:10.1029/2006JC003683

> Nozais C, Gosselin M, Michel C, Tita G (2001) Abundance, biomass, composition and grazing impact of the sea-ice meiofauna in the North Water, northern Baffin Bay. Mar Ecol Prog Ser 217:235-250

Okolodkov YB (1992) Cryopelagic flora of the Chukchi, East Siberian and Laptev seas. Proc NIPR Symp Polar Biol 5: $28-43$ 
Parsons TR, Maita Y, Lalli CM (1984a) A manual of chemical and biological methods for seawater analysis. Pergamon Press, Toronto

Parsons TR, Takahashi M, Hargrave B (1984b) Biological oceanographic processes, 3rd edn. Pergamon Press, Toronto

- Perovich DK (1990) Theoretical estimates of light reflection and transmission by spatially complex and temporally varying sea ice covers. J Geophys Res 95:9557-9567

Poulin M (1990) Family Naviculaceae: Arctic species. In: Medlin LK, Priddle J (eds) Polar marine diatoms. British Antarctic Survey, Cambridge, p 137-149

Poulin M (1993) Craspedopleura (Bacillariophyta), a new diatom genus of arctic sea ice assemblages. Phycologia 32: 223-233

Poulin M, Cardinal A (1982a) Sea ice diatoms from Manitounuk Sound, southeastern Hudson Bay (Quebec, Canada). I. Family Naviculaceae. Can J Bot 60:1263-1278

Poulin M, Cardinal A (1982b) Sea ice diatoms from Manitounuk Sound, southeastern Hudson Bay (Quebec, Canada). II. Family Naviculaceae, genus Navicula. Can J Bot 60: $2825-2845$

Poulin M, Cardinal A (1983) Sea ice diatoms from Manitounuk Sound, southeastern Hudson Bay (Quebec, Canada). III. Cymbellaceae, Entomoneidaceae, Gomphonemataceae, and Nitzschiaceae. Can J Bot 61:107-118

Poulin M, Cardinal A, Legendre L (1983) Réponse d'une communauté de diatomées de glace à un gradient de salinité (baie d'Hudson). Mar Biol 76:191-202

Ratkova TN, Wassmann P (2005) Sea ice algae in the White and Barents seas: composition and origin. Polar Res 24: 95-110

Redfield AC, Ketchum BH, Richards FA (1963) The influence of organisms on the composition of sea-water. In: Hill MN (ed) The sea, Vol 2. Interscience, New York, p 26-77

Riedel A, Michel C, Gosselin M (2006) Seasonal study of seaice exopolymeric substances on the Mackenzie shelf: implications for transport of sea-ice bacteria and algae. Aquat Microb Ecol 45:195-206

Riedel A, Michel C, Gosselin M (2007a) Grazing of largesized bacteria by sea-ice heterotrophic protists on the Mackenzie Shelf during the winter-spring transition. Aquat Microb Ecol 50:25-38

Riedel A, Michel C, Gosselin M, LeBlanc B (2007b) Enrichment of nutrients, exopolymeric substances and microorganisms in newly formed sea ice on the Mackenzie shelf. Mar Ecol Prog Ser 342:55-67

Riedel A, Michel C, Gosselin M, LeBlanc B (2008) Winterspring dynamics in sea-ice carbon cycling in the coastal Arctic Ocean. J Mar Syst 74:918-932

Różańska M, Poulin M, Gosselin M (2008) Protist entrapment in newly formed sea ice in the Coastal Arctic Ocean. J Mar Syst 74:887-901

Runge JA, Ingram RJ (1988) Underice grazing by planktonic, calanoid copepods in relation to a bloom of ice microalgae in southeastern Hudson Bay. Limnol Oceanogr 33: 280-286

Rysgaard S, Kühl M, Glud RN, Hansen JW (2001) Biomass, production and horizontal patchiness of sea ice algae in a
high-Arctic fjord (Young Sound, NE Greenland). Mar Ecol Prog Ser 223:15-26

Schnack-Schiel SB (2003) The macrobiology of sea ice. In: Thomas DN, Dieckmann GS (eds) Sea ice. An introduction to its physics, chemistry, biology and geology. Blackwell Science, Oxford, p 211-239

Seuthe L, Darnis G, Wexels Riser C, Wassmann P, Fortier L (2007) Winter-spring feeding and metabolism of Arctic copepods: insights from faecal pellet production and respiration measurements in the southeastern Beaufort Sea. Polar Biol 30:427-436

Shalchian-Tabrizi K, Eikrem W, Klaveness D, Vaulot D and others (2006) Telonemia, a new protist phylum with affinity to chromist lineages. Proc R Soc Lond B Biol Sci 273: $1833-1842$

Simard M (2003) Influence des facteurs du milieu sur la dynamique printanière des microalgues de glace de la région des Eaux du Nord (baie de Baffin). MSc thesis, Université du Québec à Rimouski

> Sime-Ngando T, Gosselin M, Juniper SK, Levasseur M (1997) Changes in sea-ice phagotrophic microprotists (20-200 $\mu \mathrm{m})$ during the spring algal bloom, Canadian Arctic Archipelago. J Mar Syst 11:163-172

Smith REH, Anning J, Clement P, Cota G (1988) Abundance and production of ice algae in Resolute Passage, Canadian Arctic. Mar Ecol Prog Ser 48:251-263

Smith REH, Harrison WG, Harris LR, Herman AW (1990) Vertical fine structure of particulate matter and nutrients in sea ice of the High Arctic. Can J Fish Aquat Sci 47: $1348-1355$

Smith REH, Gosselin M, Taguchi S (1997) The influence of major inorganic nutrients on the growth and physiology of high arctic ice algae. J Mar Syst 11:63-70

Sokal RR, Rohlf FJ (1995) Biometry: the principles and practice of statistics in biological research, 3rd edn. WH Freeman, New York

Stoecker DK, Gustafson DE, Merrell JR, Black MMD, Baier CT (1997) Excystment and growth of chrysophytes and dinoflagellates at low temperatures and high salinities in Antarctic sea-ice. J Phycol 33:585-595

Thomsen HA (1992) Plankton i de indre danske farvande. Havforskning fra Miljøstyrelsen, Vol 11. Scantryk, Copenhagen

Vézina AF, Demers S, Laurion I, Sime-Ngando T, Juniper SK, Devine L (1997) Carbon flows through the microbial food web of first-year ice in Resolute Passage (Canadian High Arctic). J Mar Syst 11:173-189

> von Quillfeldt CH (1997) Distribution of diatoms in the Northeast Water Polynya, Greenland. J Mar Syst 10:211-240

> von Quillfeldt CH, Ambrose WG, Clough LM (2003) High number of diatom species in first year-ice from the Chukchi Sea. Polar Biol 26:806-818

Welch HE, Bergmann MA (1989) Seasonal development of ice algae and its prediction from environmental factors near Resolute, N.W.T., Canada. Can J Fish Aquat Sci 46: 1793-1804

- Welch HE, Bergmann MA, Siferd TD, Amarualik PS (1991) Seasonal development of ice algae near Chesterfield Inlet, N.W.T., Canada. Can J Fish Aquat Sci 48:2395-2402 
Appendix 1. Protists recorded under high and low snow cover on landfast ice in Franklin Bay from 24 February to 20 June 2004. A: mean abundance $\left(10^{6}\right.$ cells $\left.\mathrm{m}^{-2}\right)$; $\mathrm{A}_{\text {max }}$ : maximum abundance $\left(10^{6}\right.$ cells $\left.\mathrm{m}^{-2}\right)$; A (\%): mean relative abundance (\%); Occ. $(\%)$ : number of samples in which the taxon occurred in percent (maximum of 26 and 27 samples for high $(>10 \mathrm{~cm})$ and low $(<10 \mathrm{~cm})$ snow depth, respectively); nd: taxon not detected; ${ }^{a}$ indicates colonial diatoms

\begin{tabular}{|c|c|c|c|c|c|c|c|c|}
\hline \multirow[t]{2}{*}{ Ice protist } & \multirow{2}{*}{$\mathrm{A}$} & \multicolumn{2}{|c|}{ —High snow - } & \multirow[b]{2}{*}{ Occ. $(\%)$} & \multirow{2}{*}{$\mathrm{A}$} & \multicolumn{2}{|c|}{ _ Low snow } & \multirow[b]{2}{*}{ Occ. $(\%)$} \\
\hline & & $A_{\max }$ & A $(\%)$ & & & $A_{\max }$ & $\mathrm{A}(\%)$ & \\
\hline \multicolumn{9}{|l|}{ Coscinodiscophyceae } \\
\hline Attheya decora West & 0.001 & 0.02 & 0.01 & 4 & 0.004 & 0.09 & 0.04 & 7 \\
\hline A. longicornis Crawford \& Gardner & 1.8 & 17 & 0.18 & 27 & 1.9 & 17 & 0.10 & 26 \\
\hline A. septentrionalis (Østrup) Crawford & 4.7 & 74 & 0.23 & 46 & 14 & 67 & 0.83 & 74 \\
\hline Chaetoceros sp. 2 & 0.04 & 0.62 & 0.09 & 23 & 0.01 & 0.25 & 0.02 & 7 \\
\hline Melosira arctica Dickie ${ }^{a}$ & 0.11 & 1.1 & 0.89 & 35 & 1.7 & 37 & 0.20 & 22 \\
\hline Porosira glacialis (Grunow) Jørgensen & 0.01 & 0.16 & 0.03 & 8 & nd & nd & nd & 0 \\
\hline Thalassiosira spp. & 0.06 & 0.64 & 0.05 & 23 & 0.01 & 0.16 & 0.03 & 7 \\
\hline Unidentified centric cells & 0.49 & 9.0 & 0.24 & 46 & 0.13 & 2.1 & 0.05 & 19 \\
\hline \multicolumn{9}{|l|}{ Fragilariophyceae } \\
\hline $\begin{array}{l}\text { Synedropsis hyperborea (Grunow) Hasle, Medlin \& } \\
\text { Syvertsen }^{\mathrm{a}}\end{array}$ & 4.4 & 70 & 0.33 & 69 & 10 & 82 & 0.74 & 78 \\
\hline \multicolumn{9}{|l|}{ Bacillariophyceae } \\
\hline Amphora laevis var. laevissima (Gregory) Cleve & 0.65 & 3.8 & 0.36 & 73 & 0.27 & 2.5 & 0.16 & 41 \\
\hline \multicolumn{9}{|l|}{ Witkowski, Lange-Bertalot \& Metzeltin } \\
\hline Biremis ambigua (Cleve) Mann & 0.003 & 0.08 & $<0.01$ & 4 & 0.02 & 0.41 & $<0.01$ & 4 \\
\hline Craspedopleura kryophila (Cleve) Poulin & 0.10 & 1.4 & 0.04 & 27 & 0.07 & 1.1 & 0.03 & 22 \\
\hline Cylindrotheca closterium (Ehrenberg) Reimann \& Lewin & 1.9 & 2.0 & 12.7 & 88 & 2.2 & 2.9 & 16 & 93 \\
\hline Diploneis litoralis var. arctica Cleve & 1.3 & 7.6 & 0.51 & 19 & 0.58 & 2.9 & 0.39 & 4 \\
\hline D. litoralis var. clathrata (Østrup) Cleve & 0.08 & 0.75 & 0.06 & 77 & 0.01 & 0.21 & $<0.01$ & 52 \\
\hline \multicolumn{8}{|l|}{ Poulin \& Cardinal } & 41 \\
\hline E. kjellmanii (Cleve) Poulin \& Cardinal $^{\mathrm{a}}$ & 4.7 & 49 & 0.73 & 96 & 8.4 & 55 & 0.66 & 93 \\
\hline E. kjellmanii var. kariana (Grunow) Poulin \& Cardinal ${ }^{a}$ & 2.1 & 17 & 0.26 & 54 & 6.2 & 24 & 0.50 & 81 \\
\hline E. kjellmanii var. subtilis (Grunow) Poulin \& Cardinal & 0.07 & 1.0 & 0.03 & 12 & 0.12 & 1.2 & 0.03 & 19 \\
\hline E. paludosa (W. Smith) Poulin \& Cardinal & 0.005 & 0.12 & $<0.01$ & 4 & 0.08 & 2.1 & 0.01 & 4 \\
\hline E. paludosa var. hyperborea (Grunow) Poulin \& Cardinal & 0.64 & 4.0 & 0.12 & 54 & 0.49 & 4.2 & 0.08 & 48 \\
\hline Entomoneis spp. & 0.67 & 4.2 & 0.23 & 46 & 0.63 & 4.1 & 0.10 & 41 \\
\hline $\begin{array}{l}\text { Fallacia forcipata var. densestriata (Schmidt) Stickle \& } \\
\text { Mann }\end{array}$ & 0.15 & 1.1 & 0.07 & 38 & 0.09 & 1.6 & 0.06 & 19 \\
\hline Fragilariopsis cylindrus (Grunow) Krieger ${ }^{\mathrm{a}}$ & 8.4 & 48 & 3.0 & 81 & 11 & 56 & 2.7 & 78 \\
\hline F. oceanica (Cleve) Hasle ${ }^{a}$ & 0.72 & 12 & 0.14 & 12 & 1.0 & 15 & 0.06 & 7 \\
\hline Gyrosigma concilians (Cleve) Okolodkov & 0.74 & 3.0 & 0.52 & 81 & 0.51 & 2.3 & 0.27 & 48 \\
\hline G. hudsonii Poulin \& Cardinal & 0.24 & 2.2 & 0.03 & 27 & 0.14 & 2.0 & 0.03 & 22 \\
\hline G. tenuissimum var. hyperborea (Grunow) Cleve & 0.51 & 3.2 & 0.44 & 65 & 0.36 & 2.0 & 0.28 & 52 \\
\hline Gyrosigma / Pleurosigma complex & 0.57 & 3.1 & 0.38 & 65 & 0.46 & 2.3 & 0.14 & 52 \\
\hline Haslea crucigeroides (Hustedt) Simonsen & 0.74 & 2.8 & 0.46 & 81 & 1.0 & 4.2 & 0.37 & 74 \\
\hline H. kjellmanii (Cleve) Simonsen & 0.32 & 3.3 & 0.03 & 23 & 0.19 & 2.1 & 0.01 & 15 \\
\hline H. spicula (Hickie) Lange-Bertalot & 0.52 & 3.3 & 0.28 & 54 & 0.48 & 4.2 & 0.22 & 41 \\
\hline H. vitrea (Cleve) Simonsen & 0.09 & 2.2 & 0.01 & 12 & 0.02 & 0.41 & 0.02 & 7 \\
\hline $\begin{array}{l}\text { Kurpiszia kryokonites (Cleve) Witkowski, } \\
\text { Lange-Bertalot \& Metzeltin }\end{array}$ & 0.27 & 2.1 & 0.18 & 46 & 0.30 & 4.2 & 0.16 & 30 \\
\hline $\begin{array}{l}\text { K. subprotracta (Cleve) Witkowski, Lange-Bertalot \& } \\
\text { Metzeltin }\end{array}$ & 0.03 & 0.54 & 0.02 & 15 & 0.02 & 0.41 & 0.04 & 11 \\
\hline Manguinea rigida (M. Peragallo) Paddock & 0.07 & 1.1 & 0.03 & 19 & 0.45 & 5.2 & 0.05 & 19 \\
\hline Meuniera membranacea (Cleve) Silva & 0.78 & 5.2 & 0.25 & 69 & 0.61 & 2.9 & 0.18 & 59 \\
\hline Navicula algida Grunow & 0.22 & 2.2 & 0.07 & 35 & 0.27 & 2.0 & 0.04 & 37 \\
\hline N. directa (W. Smith) Ralfs & 2.2 & 11 & 1.2 & 88 & 2.2 & 13 & 0.89 & 74 \\
\hline N. gelida Grunow & 0.27 & 2.3 & 0.23 & 38 & 0.23 & 1.6 & 0.20 & 37 \\
\hline N. gelida var. manitounukensis Poulin \& Cardinal & 0.01 & 0.38 & 0.01 & 4 & nd & nd & nd & 0 \\
\hline N. gelida var. radissonii Poulin \& Cardinal & 2.1 & 9.1 & 1.4 & 88 & 1.3 & 5.6 & 0.60 & 67 \\
\hline N. cf. impexa Hustedt sensu Poulin \& Cardinal & 0.16 & 1.6 & 0.19 & 38 & 0.13 & 1.0 & 0.10 & 33 \\
\hline N. kariana Grunow & 0.001 & 0.02 & 0.01 & 4 & 0.02 & 0.4 & $<0.01$ & 7 \\
\hline N. kariana var. detersa Grunow & 0.76 & 4.3 & 0.15 & 58 & 0.34 & 2.1 & 0.18 & 44 \\
\hline N. kariana var. frigida (Grunow) Cleve & 0.01 & 0.28 & 0.02 & 15 & 0.02 & 0.41 & $<0.01$ & 4 \\
\hline N. lineola var. perlepida (Grunow) Cleve & 0.01 & 0.20 & $<0.01$ & 4 & 0.03 & 0.82 & 0.02 & 7 \\
\hline N. pelagica Cleve $\mathrm{a}^{\mathrm{a}}$ & 25.5 & 195 & 2.8 & 77 & 30 & 152 & 3.2 & 93 \\
\hline N. pellucidula Hustedt & 0.39 & 2.4 & 0.14 & 50 & 0.20 & 1.4 & 0.06 & 37 \\
\hline N. recurvata Gran & 0.01 & 0.17 & 0.01 & 8 & 0.10 & 2.0 & 0.01 & 11 \\
\hline N. septentrionalis (Grunow) Gran ${ }^{\mathrm{a}}$ & 20.5 & 178 & 1.6 & 62 & 40 & 316 & 2.0 & 63 \\
\hline
\end{tabular}


Appendix 1 (continued)

\begin{tabular}{|c|c|c|c|c|c|c|c|c|}
\hline \multirow[t]{2}{*}{ Ice protist } & \multicolumn{4}{|c|}{ High snow } & \multicolumn{4}{|c|}{ _ Low snow } \\
\hline & $\mathrm{A}$ & $A_{\max }$ & $\mathrm{A}(\%)$ & Occ. $(\%)$ & A & $\mathrm{A}_{\max }$ & $\mathrm{A}(\%)$ & Occ. $(\%)$ \\
\hline N. superba Cleve & 0.09 & 1.0 & 0.03 & 23 & 0.01 & 0.21 & 0.01 & 7 \\
\hline N. superba var. elliptica Cleve & 0.02 & 0.38 & 0.02 & 8 & 0.02 & 0.41 & $<0.01$ & 4 \\
\hline N. superba var. subacuta Gran & 0.02 & 0.38 & 0.01 & 8 & nd & nd & nd & 0 \\
\hline N. superba group & nd & nd & nd & 0 & 0.04 & 1.0 & 0.01 & 7 \\
\hline N. transitans Cleve & 0.13 & 1.3 & 0.08 & 31 & 0.20 & 2.3 & 0.13 & 30 \\
\hline N. transitans var. derasa (Grunow) Cleve & 0.45 & 2.8 & 0.25 & 58 & 0.18 & 2.9 & 0.09 & 22 \\
\hline N. transitans var. derasa f. delicatula Heimdal & 0.07 & 1.4 & 0.03 & 19 & 0.03 & 0.62 & 0.02 & 11 \\
\hline N. transitans / kariana complex & 0.06 & 0.54 & 0.04 & 27 & 0.002 & 0.04 & 0.01 & 4 \\
\hline N. transitans group & 0.65 & 2.8 & 0.47 & 69 & 0.13 & 2.1 & 0.16 & 26 \\
\hline N. trigonocephala Cleve & 0.09 & 0.64 & 0.04 & 35 & 0.10 & 2.1 & 0.06 & 22 \\
\hline N. trigonocephala var. depressa Østrup & 0.10 & 1.0 & 0.04 & 23 & 0.06 & 0.98 & 0.01 & 15 \\
\hline N. valida Cleve \& Grunow & 0.06 & 0.80 & 0.02 & 19 & 0.04 & 0.83 & 0.01 & 11 \\
\hline N. valida var. minuta Cleve & 0.10 & 1.4 & 0.05 & 31 & 0.04 & 0.41 & 0.04 & 15 \\
\hline N. vanhoeffenii Gran ${ }^{\mathrm{a}}$ & 3.9 & 92 & 0.28 & 19 & 3.0 & 37 & 0.23 & 22 \\
\hline Navicula sp. 1 & 0.08 & 1.3 & 0.21 & 12 & 0.12 & 2.1 & 0.12 & 11 \\
\hline Navicula sp. 2 & 3.8 & 76 & 0.63 & 54 & 2.2 & 15.3 & 0.65 & 48 \\
\hline Navicula sp. 5 & 0.65 & 7.0 & 0.13 & 38 & 1.2 & 9.2 & 0.18 & 37 \\
\hline Navicula sp. $6^{\mathrm{a}}$ & 53.1 & 325 & 4.6 & 50 & 93 & 493 & 5.5 & 81 \\
\hline Navicula sp. 12 & 0.70 & 4.4 & 0.38 & 46 & 1.4 & 10 & 0.22 & 56 \\
\hline Navicula spp. & 2.2 & 20 & 0.83 & 92 & 3.6 & 28 & 0.45 & 85 \\
\hline Nitzschia angularis W. Smith & 0.09 & 2.2 & 0.02 & 12 & 0.21 & 4.2 & 0.08 & 26 \\
\hline N. arctica Cleve ${ }^{\mathrm{a}}$ & 4.4 & 39 & 1.8 & 69 & 7.6 & 32 & 1.7 & 78 \\
\hline N. brebissonii var. borealis Grunow ex Cleve & 0.09 & 1.4 & 0.03 & 15 & 0.11 & 1.5 & 0.01 & 11 \\
\hline N. distans var. erratica Cleve $^{a}$ & 0.08 & 1.3 & 0.23 & 23 & 0.05 & 0.42 & 0.10 & 19 \\
\hline N. frigida Grunow ${ }^{\mathrm{a}}$ & 236 & 2562 & 17 & 92 & 465 & 1326 & 35 & 100 \\
\hline N. laevissima Grunow & 0.29 & 3.3 & 0.05 & 27 & 1.6 & 29 & 0.08 & 33 \\
\hline N. lanceolata var. pygmaea Cleve & 0.01 & 0.16 & $<0.01$ & 8 & 0.08 & 2.1 & 0.01 & 4 \\
\hline N. longissima (Brébisson) Ralfs & 1.8 & 23 & 0.64 & 73 & 0.89 & 4.5 & 0.77 & 52 \\
\hline N. neofrigida Medlin ${ }^{\mathrm{a}}$ & 5.8 & 50 & 0.38 & 54 & 13 & 43 & 0.97 & 67 \\
\hline N. promare Medlin ${ }^{\mathrm{a}}$ & 30.1 & 167 & 3.4 & 81 & 84 & 300 & 6.0 & 85 \\
\hline N. scabra Cleve & 0.26 & 4.2 & 0.09 & 35 & 0.14 & 2.1 & 0.03 & 22 \\
\hline Nitzschia sp. 1 & 0.02 & 0.32 & 0.02 & 12 & 0.41 & 10 & 0.02 & 7 \\
\hline Nitzschia spp. & 2.4 & 20.9 & 0.52 & 73 & 9.4 & 66 & 0.64 & 81 \\
\hline Pauliella taeniata (Grunow) Round \& Basson ${ }^{a}$ & 3.7 & 75 & 0.45 & 19 & 8.3 & 78 & 0.53 & 30 \\
\hline $\begin{array}{l}\text { Petroneis glacialis (Cleve) Witkowski, } \\
\text { Lange-Bertalot \& Metzeltin }\end{array}$ & 0.16 & 2.1 & 0.11 & 38 & 0.08 & 1.2 & 0.05 & 19 \\
\hline Pinnularia quadratarea (Schmidt) Cleve & 0.21 & 2.8 & 0.06 & 23 & 0.03 & 0.83 & 0.01 & 4 \\
\hline P. quadratarea var. bicontracta (Østrup) Heiden & 0.09 & 1.4 & 0.04 & 23 & 0.002 & 0.06 & 0.01 & 4 \\
\hline P. quadratarea var. capitata Heiden & 0.005 & 0.1 & $<0.01$ & 4 & 0.002 & 0.03 & 0.01 & 4 \\
\hline P. quadratarea var. constricta (Østrup) Heiden & 0.13 & 1.3 & 0.04 & 19 & 0.02 & 0.42 & 0.01 & 7 \\
\hline P. quadratarea var. densestriata Cleve & 0.35 & 2.2 & 0.28 & 62 & 0.09 & 0.83 & 0.14 & 33 \\
\hline P. quadratarea var. maxima (Østrup) Boyer & 0.05 & 0.80 & 0.02 & 15 & nd & nd & nd & 0 \\
\hline P. quadratarea group & 0.06 & 0.77 & 0.09 & 12 & 0.002 & 0.06 & 0.01 & 4 \\
\hline P. semiinflata (Østrup) Gran & 0.07 & 0.80 & 0.01 & 12 & 0.11 & 2.1 & 0.07 & 19 \\
\hline Plagiotropis spp. & 0.17 & 2.2 & 0.03 & 27 & 0.54 & 6.1 & 0.06 & 26 \\
\hline Pleurosigma clevei Grunow & 0.02 & 0.49 & 0.01 & 8 & 0.03 & 0.41 & 0.01 & 11 \\
\hline P. stuxbergii Cleve \& Grunow & 0.23 & 1.6 & 0.06 & 35 & 0.17 & 0.98 & 0.06 & 41 \\
\hline P. stuxbergii var. rhomboides (Cleve) Cleve & 0.09 & 0.86 & 0.08 & 35 & 0.25 & 2.1 & 0.07 & 41 \\
\hline Pseudogomphonema arcticum (Grunow) Medlin ${ }^{\mathrm{a}}$ & 3.6 & 31 & 0.36 & 81 & 3.8 & 17 & 0.29 & 78 \\
\hline P. groenlandicum (Østrup) Medlin & 0.02 & 0.64 & $<0.01$ & 4 & 0.21 & 2.1 & 0.02 & 19 \\
\hline Pseudo-nitzschia delicatissima (Cleve) Heiden ${ }^{\mathrm{a}}$ & 0.01 & 0.25 & 0.03 & 12 & 0.13 & 3.0 & 0.01 & 7 \\
\hline P. cf. pseudodelicatissima (Hasle) Hasle ${ }^{\mathrm{a}}$ & 7.2 & 45 & 1.2 & 85 & 21 & 105 & 1.5 & 85 \\
\hline P. pungens (Grunow ex Cleve) Hasle ${ }^{a}$ & 0.11 & 2.8 & $<0.01$ & 4 & 0.11 & 2.1 & $<0.01$ & 7 \\
\hline P. seriata (Cleve) H. Peragallo ${ }^{a}$ & 0.56 & 5.8 & 0.17 & 38 & 0.21 & 2.5 & 0.03 & 15 \\
\hline P. turgidula (Hustedt) Hasle ${ }^{\mathrm{a}}$ & 0.10 & 1.0 & 0.02 & 12 & 0.23 & 6.2 & 0.01 & 4 \\
\hline Pseudo-nitzschia spp. ${ }^{\text {a }}$ & 1.7 & 15 & 0.18 & 58 & 3.0 & 25 & 0.15 & 52 \\
\hline Stauroneis radissonii Poulin \& Cardinal & 0.67 & 5.2 & 0.18 & 69 & 0.47 & 2.9 & 0.16 & 52 \\
\hline Stenoneis inconspicua var. baculus (Cleve) Cleve $^{\mathrm{a}}$ & 0.47 & 7.0 & 0.08 & 15 & 0.56 & 6.2 & 0.07 & 22 \\
\hline S. obtuserostrata (Hustedt) Poulin & 0.73 & 3.2 & 0.41 & 81 & 0.84 & 6.2 & 0.29 & 63 \\
\hline Unidentified pennate cells & 14.3 & 93 & 4.2 & 100 & 71 & 448 & 7.1 & 100 \\
\hline Pennate sp. 1 & 0.16 & 3.2 & 0.04 & 19 & 0.28 & 3.3 & 0.07 & 22 \\
\hline Pennate sp. 2 & 0.02 & 0.6 & $<0.01$ & 4 & 0.01 & 0.09 & 0.02 & 7 \\
\hline Pennate sp. 8 & 0.11 & 1.2 & 0.10 & 31 & 0.16 & 3.1 & 0.05 & 19 \\
\hline
\end{tabular}


Appendix 1 (continued)

\begin{tabular}{|c|c|c|c|c|c|c|c|c|}
\hline \multirow[t]{2}{*}{ Ice protist } & \multicolumn{4}{|c|}{ - High snow } & \multicolumn{4}{|c|}{ _ Low snow - } \\
\hline & A & $A_{\max }$ & $\mathrm{A}(\%)$ & Occ. $(\%)$ & A & $\mathrm{A}_{\max }$ & $\mathrm{A}(\%)$ & Occ. $(\%)$ \\
\hline \multicolumn{9}{|l|}{ Dinophyceae } \\
\hline Amphidinium sphenoides Wülff & 0.001 & 0.02 & 0.01 & 4 & 0.02 & 0.41 & $<0.01$ & 4 \\
\hline Dinophysis acuminata Claparède \& Lachmann & 0.005 & 0.08 & 0.02 & 8 & nd & nd & nd & 0 \\
\hline Gymnodinium sp. 1 sensu Bérard-Therriault et al. & 0.003 & 0.08 & $<0.01$ & 4 & nd & nd & nd & 0 \\
\hline Gymnodinium / Gyrodinium complex & 0.54 & 6.8 & 0.24 & 50 & 0.33 & 5.0 & 0.06 & 26 \\
\hline Heterocapsa arctica Horiguchi & 0.14 & 1.1 & 0.05 & 31 & 0.20 & 1.0 & 0.04 & 33 \\
\hline Heterocapsa spp. & 0.11 & 1.4 & 0.03 & 15 & 0.21 & 3.9 & 0.02 & 19 \\
\hline Peridiniella catenata (Levander) Balech & 0.36 & 6.5 & 0.07 & 15 & 0.13 & 2.1 & 0.02 & 7 \\
\hline Protoperidinium spp. & 0.02 & 0.63 & $<0.01$ & 4 & nd & nd & nd & 0 \\
\hline Dinophyceae spp. & 0.26 & 3.1 & 0.25 & 46 & 0.37 & 3.7 & 0.09 & 26 \\
\hline Thecate dinophyceae & 0.01 & 0.30 & 0.02 & 12 & 0.16 & 4.1 & 0.02 & 7 \\
\hline \multicolumn{9}{|l|}{ Chrysophyceae } \\
\hline Dinobryon faculiferum (Willén) Willén & 0.41 & 4.3 & 0.07 & 27 & 1.4 & 8.2 & 0.18 & 63 \\
\hline Chrysophyceae sp. 1 sensu & nd & nd & nd & 0 & 0.06 & 1.5 & $<0.01$ & 4 \\
\hline \multicolumn{9}{|l|}{ Bérard-Therriault et al. } \\
\hline Chrysophyceae spp. & 0.01 & 0.25 & 0.01 & 4 & nd & nd & nd & 0 \\
\hline \multicolumn{9}{|l|}{ Choanoflagellidea } \\
\hline Monosiga marina Grøntved & nd & nd & nd & 0 & 0.08 & 1.6 & 0.01 & 7 \\
\hline Choanoflagellidea sp. 1 & 3.8 & 52 & 0.21 & 12 & nd & nd & nd & 0 \\
\hline Choanoflagellidea spp. & 4.4 & 31 & 0.34 & 38 & 5.5 & 70 & 0.23 & 33 \\
\hline \multicolumn{9}{|l|}{ Cryptophyceae } \\
\hline Hemiselmis virescens Droop & 0.17 & 2.5 & 0.14 & 23 & 0.05 & 0.75 & 0.03 & 15 \\
\hline $\begin{array}{l}\text { Plagioselmis prolonga Butcher ex Novarino, Lucas \& } \\
\text { Morrall }\end{array}$ & 0.03 & 0.85 & 0.01 & 8 & nd & nd & nd & 0 \\
\hline Rhodomonas maculata Butcher ex Hill \& Wetherbee & 0.28 & 2.6 & 0.20 & 31 & 0.15 & 2.1 & 0.04 & 19 \\
\hline Teleaulax spp. & 0.06 & 1.3 & 0.03 & 15 & nd & nd & nd & 0 \\
\hline Cryptophyceae spp. & 5.7 & 34 & 2.2 & 88 & 5.5 & 30 & 0.97 & 85 \\
\hline \multicolumn{9}{|l|}{ Dictyochophyceae } \\
\hline Apedinella spinifera (Throndsen) Throndsen & 0.005 & 0.13 & 0.01 & 4 & nd & nd & nd & 0 \\
\hline Dictyocha speculum Ehrenberg & 0.005 & 0.13 & 0.01 & 4 & nd & nd & nd & 0 \\
\hline \multicolumn{9}{|l|}{ Euglenophyceae } \\
\hline Eutreptia spp. & 0.001 & 0.04 & 0.01 & 4 & 0.002 & 0.06 & 0.01 & 4 \\
\hline Eutreptiella braarudii Throndsen & 0.12 & 1.8 & 0.07 & 23 & 0.02 & 0.49 & $<0.01$ & 4 \\
\hline Euglenophyceae spp. & 0.56 & 4.2 & 0.14 & 50 & 0.50 & 5.5 & 0.05 & 30 \\
\hline \multicolumn{9}{|l|}{ Prasinophyceae } \\
\hline Pyramimonas cf. nansenii Braarud & 0.42 & 6.5 & 0.08 & 12 & 0.02 & 0.41 & $<0.01$ & 4 \\
\hline$P$. virginica Pennick & 0.01 & 0.17 & 0.08 & 8 & 0.14 & 3.9 & $<0.01$ & 4 \\
\hline Pyramimonas spp. & 0.81 & 13 & 0.19 & 38 & 0.45 & 4.9 & 0.06 & 30 \\
\hline Prasinophyceae spp. & 0.60 & 7.1 & 0.14 & 38 & 0.36 & 4.6 & 0.12 & 41 \\
\hline \multicolumn{9}{|l|}{ Prymnesiophyceae } \\
\hline Prymnesiophyceae spp. & 0.13 & 2.3 & 0.04 & 15 & 0.30 & 4.6 & 0.02 & 15 \\
\hline \multicolumn{9}{|l|}{ Chlorophyceae } \\
\hline $\begin{array}{l}\text { Chlainomonas cf. rubra } \\
\text { (Stein \& Brooke) Honam }\end{array}$ & 0.88 & 5.4 & 0.50 & 69 & 0.92 & 7.0 & 0.57 & 52 \\
\hline Chlorophyceae sp. 1 & nd & nd & nd & 0 & 0.004 & 0.01 & 0.03 & 4 \\
\hline Chlorophyceae spp. & 1.5 & 16 & 0.32 & 46 & 2.0 & 14 & 0.15 & 41 \\
\hline \multicolumn{9}{|l|}{ Heterotrophic flagellates } \\
\hline Telonema subtilis Griessmann & 1.1 & 13 & 0.25 & 35 & 0.42 & 7.8 & 0.03 & 19 \\
\hline \multicolumn{9}{|l|}{ Unidentified flagellates } \\
\hline Flagellate sp. 2 & 0.1 & 2.5 & 0.05 & 15 & 0.002 & 0.06 & 0.01 & 4 \\
\hline Flagellates $\leq 5 \mu \mathrm{m}$ & 60.5 & 398 & 16 & 100 & 76 & 381 & 7.1 & 100 \\
\hline Flagellates $6-10 \mu \mathrm{m}$ & 47.7 & 350 & 14 & 96 & 61 & 394 & 6.3 & 100 \\
\hline Flagellates $>10 \mu \mathrm{m}$ & 6.0 & 47 & 2.3 & 88 & 9.8 & 60 & 1.3 & 93 \\
\hline Number of species & & & & 119 & & & & 112 \\
\hline Number of taxa & & & & 149 & & & & 140 \\
\hline
\end{tabular}

Editorial responsibility: Hans Heinrich Janssen, Oldendorf/Luhe, Germany
Submitted: October 2, 2008; Accepted: May 4, 2009

Proofs received from author(s): June 26, 2009 